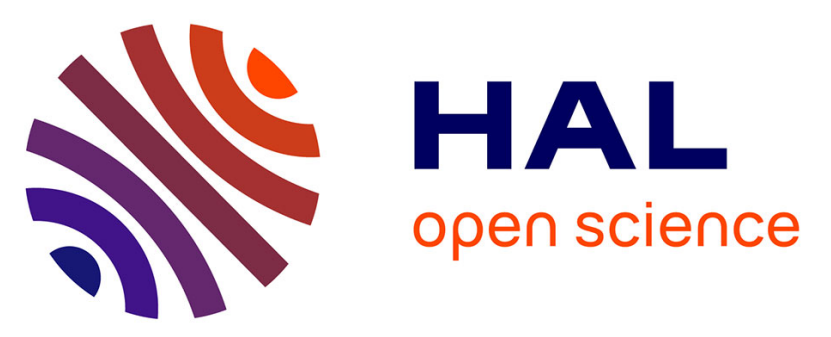

\title{
Emplacement in an extensional setting of the Mont Lozère-Borne granitic complex (SE France) inferred from comprehensive AMS, structural and gravity studies.
}

Jean-Yves Talbot, Guillaume Martelet, Gabriel Courrioux, Yan Chen, Michel Faure

\section{To cite this version:}

Jean-Yves Talbot, Guillaume Martelet, Gabriel Courrioux, Yan Chen, Michel Faure. Emplacement in an extensional setting of the Mont Lozère-Borne granitic complex (SE France) inferred from comprehensive AMS, structural and gravity studies.. Journal of Structural Geology, 2004, 206, pp.3-4, 11-28. 10.1016/S0191-8141(03)00083-X . hal-00023878

\section{HAL Id: hal-00023878 \\ https://hal-insu.archives-ouvertes.fr/hal-00023878}

Submitted on 19 May 2006

HAL is a multi-disciplinary open access archive for the deposit and dissemination of scientific research documents, whether they are published or not. The documents may come from teaching and research institutions in France or abroad, or from public or private research centers.
L'archive ouverte pluridisciplinaire HAL, est destinée au dépôt et à la diffusion de documents scientifiques de niveau recherche, publiés ou non, émanant des établissements d'enseignement et de recherche français ou étrangers, des laboratoires publics ou privés. 


\title{
Emplacement in an extensional setting of the Mont Lozère-Borne granitic complex (SE France) inferred from comprehensive AMS, structural and gravity studies
}

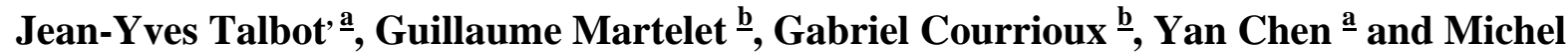 \\ Faure ${ }^{\mathbf{a}}$ \\ a Institut des Sciences de la Terre d'Orléans, UMR 6113, Université d'Orléans, BP 6759, \\ 45067, Orléans Cedex 2, France \\ ${ }^{\mathrm{b}}$ Bureau de Recherches Géologiques et Minières, BP 6009, 45060, Orléans Cedex 2, France
}

\section{Abstract}

The emplacement mode and setting of the Late Hercynian Mont Lozère-Borne granitic complex (French Massif Central), which consists of several plutons, is investigated. Structural and anisotropy of magnetic susceptibility (AMS) studies have been carried out to characterize the internal fabrics of the granitic plutons. Throughout the Pont-de-MontvertBorne pluton, an E-W-trending magnetic lineation is well developed. In the host rock and the thermal aureole, a conspicuous $E-W$-trending lineation is interpreted as an evidence of a late-orogenic extensional event. To the east of the pluton, the AMS fabric is characterized by values of anisotropy degree $\left(P^{\prime}\right)$ around $4-5 \%$ with a prolate ellipsoid and subsolidus structures, whereas, to the west, the $P^{\prime}$ parameter is weaker with an oblate ellipsoid and purely magmatic microstructures. A gravity investigation allows determination of the $3 D$ shape of the pluton. The western part of the granitic complex is thicker than the eastern one and is interpreted as the feeder zone. This suggests an eastward spreading of the magma. The consistency between regional stretching and directions of AMS lineations in the pluton and the shape of the complex deduced from gravity strongly argues that the emplacement mode of the complex was influenced by the regional extensional tectonic setting during the collapse of the Hercynian belt.

Author Keywords: Author Keywords: Anisotropy of magnetic susceptibility (AMS); Gravity; 3D modelling; Granitic pluton; French Massif Central

\section{Introduction}

It is now well established that in collisional orogens, crustal thickening is responsible for magma production. This magmatism is triggered by compression, and many works were presented in which melting, ascent and emplacement of granitic magmas are associated with contraction or transpression tectonics (D'Lemos et al., 1992 and Brown and Solar, 1998). However, during the late stages of orogeny, the collapse of the mountain belt is accommodated by ductile extensional tectonics and magma genesis ( Brown and Talbot, 1989 and Malavieille, 1993). Although examples of granites emplaced during this late-orogenic extensional phase have been recognized in several belts, such plutons are not well documented ( Scaillet et al., 1995). This study intends to illustrate the characteristic patterns that are recorded in such types of granites from the Hercynian Belt of France.

For the last two decades, two methods have proven to be helpful to investigate granite plutons, anisotropy of magnetic susceptibility (AMS) and gravity. AMS is a powerful 
technique to measure internal fabrics of granites, particularly, in plutons where these fabrics are cryptic (Borradaile and Kehlenbeck, 1996 and Bouchez, 1997). The magnetic fabric patterns have been interpreted as a record either of the internal dynamics of the magma chamber or of the regional tectonics ( Benn et al., 1997; Benn et al., 2001 and Gleizes et al., 1997). However, these planar and linear anisotropies reflect only the deformation at the exposed level of the pluton and do not provide information on deep structures. On the contrary, the gravity field is influenced by the granitic mass and therefore allows the description of the shape of the pluton at depth, its thickness variations and the location of possible root zones (e.g. Vigneresse, 1990 and Lyons et al., 1996). Joint studies using AMS and gravity data have been already carried out to infer the 3D shape (from gravity) and the regional deformation during emplacement (from AMS) of several plutons (e.g. Améglio et al., 1997 and Vigneresse and Bouchez, 1997). By combining these two tools, an emplacement model for a given pluton can also be proposed.

This paper deals with such an integrated study of the Late Hercynian Mont Lozère-Borne granitic complex, located in the southeastern part of the French Massif Central (Fig. 1). The tectonic setting of this area at the time of the pluton emplacement, still compressional or already extensional, is still debated (Fernandez, 1977; Faure et al., 1992 and Faure, 1995). Furthermore, since this granitic complex yields geochronological constraints, determining the regional deformation that prevailed during the pluton emplacement is useful for understanding the change from a compressional tectonic event to an extensional tectonic event in this part of the Hercynian orogen. Through our AMS and gravity investigations and the building of a 3D model, we present new insights on the shape of the pluton and on the deformation recorded by the pluton fabric. These new data comply with the previous hypothesis that the Mont LozèreBorne granitic complex was emplaced during the regional late-orogenic extensional deformation (Faure, 1995). 


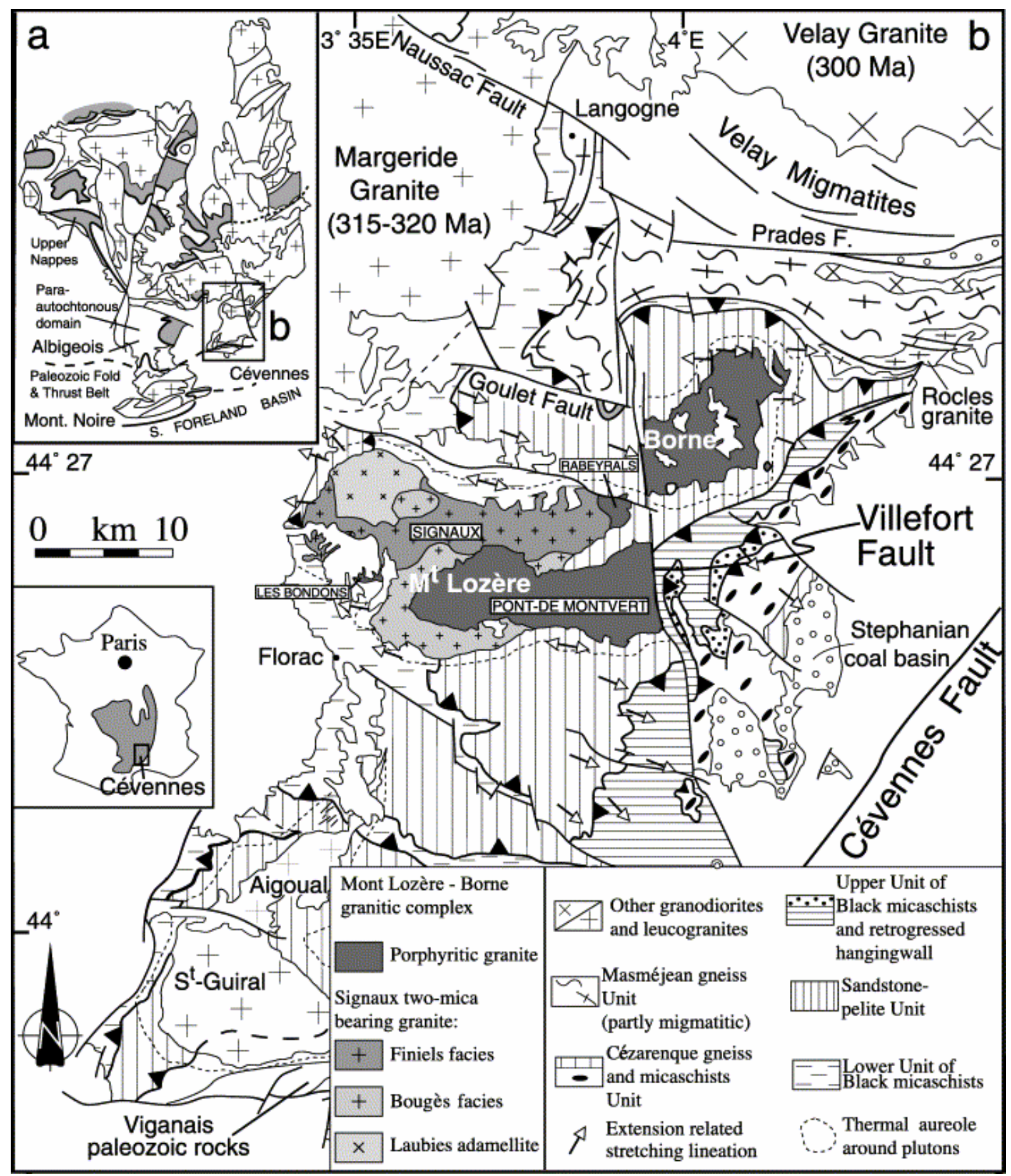

Fig. 1. (a) Location map of the study area in the French Massif Central. (b) Structural map of the Cévennes area. In the Mont Lozère-Borne granitic complex, the different facies labelled with crosses represent the Signaux two-mica granite. White arrows, which point to the sense of shear of the upper part, are extension related lineations.

\section{Geological setting}




\subsection{Regional framework}

The geological evolution of the Variscan French Massif Central results from the Paleozoic collision between Gondwana and Laurussia (Matte, 1986). The nappe stacking began in Silurian time and was associated with a HP-MT metamorphism due to subduction. During Devonian, a fast exhumation of HP rocks associated with a migmatization, an unstable sedimentation and a mafic magmatism was interpreted as evidence for a rifting event in the North Massif Central ( Faure et al., 1997). A new shortening event accompanied by granitic magmatism occurred during Late Devonian-Early Carboniferous. In the South Massif Central, this shortening event is accommodated by a ductile and synmetamorphic thrusting dated at 340-330 Ma ( Caron, 1994). Then, the entire belt experienced a late-orogenic extension at about 330-310 Ma during which several granitic plutons were emplaced ( Faure, $\underline{1995)}$.

The Cévennes area, located in the south-eastern part of the French Massif Central (Fig. 1a), belongs to the para-autochthonous unit upon which more internal and more metamorphic units were overthrusted during the Early Visean time ( Ledru et al., 1989). This paraautochthonous unit consists of a micaschist-quartzite series that underwent a prograde greenschist to lower amphibolite facies metamorphism ( Rakib, 1996). The main regional structure of this area is a flat-lying foliation (S1) with a N-S- to NE-SW-trending lineation (L1) related to the southward thrusting during the Hercynian compression ( Mattauer and Etchecopar, 1977; Matte, 1986 and Faure et al., 2001). The related metamorphism occurred between 340 and $330 \mathrm{Ma}\left({ }^{40} \mathrm{Ar} /{ }^{39} \mathrm{Ar}\right.$ method on biotite and muscovite; Caron, 1994). The Cévennes area experienced a second tectonic event around 320-310 Ma which is characterized by an E-W- to NW-SE-trending stretching lineation and shear bands cutting the older S1 foliation. The second generation of structures, developed under greenschist facies metamorphism, is attributed to a late-orogenic extensional event (Faure, 1995 and Faure et al., 2001). Several granitic plutons, namely Aigoual-St-Guiral-Liron and Mont Lozère-Borne (Fig. 1b), intruded the Cévennes units. Therefore, the emplacement mode and/or internal fabric of the Mont Lozère-Borne complex might record this tectonic regime.

\subsection{Mont Lozère-Borne granitic complex}

The Mont Lozère massif consists mainly of two petrographic facies, the Signaux two-mica granite and the Pont-de-Montvert porphyritic granodiorite (Van Moort, 1966). The Signaux two-mica granite is subdivided into three subfacies according to the amount of muscovite and cordierite: the muscovite-poor Bougès facies, the muscovite-rich Finiels facies and the cordierite-bearing Laubies adamellite ( $\underline{\text { Fig. 1b }})$. This granite surrounds the western part of the Pont-de-Montvert porphyritic granodiorite. This granodiorite is characterized by the occurrence of large-sized (up to $10 \mathrm{~cm}$ ) K-feldspar megacrysts. Two small bodies, Les Bondons and Rabeyrals, with different porphyritic facies from the Pont-de-Montvert one, also belong to the Mont Lozère massif ( $\underline{\text { Fig. } 1 \mathrm{~b}}$ ). Toward the northeast, the Borne porphyritic granodiorite is the former eastern part of the Pont-de-Montvert granodiorite pluton ( Fig. 1b). The granodioritic pluton was cut in two parts by the Permian sinistral Villefort fault resulting in a 12-km-offset between the Pont-de-Montvert and Borne massifs, which therefore belong to a single pluton, the Pont-de-Montvert-Borne porphyritic granodiorite. All these facies, from Mont Lozère and Borne massifs, form the Mont Lozère-Borne granitic complex.

This complex was emplaced at the end of the Hercynian orogeny in Namurian time. $\mathrm{Rb}-\mathrm{Sr}$ dating on whole rock yields an age of $315 \pm 5 \mathrm{Ma}$ in the Borne granodiorite (Mialhe, 1980). 
$\mathrm{U} / \mathrm{Pb}$ monazite dating provides ages of $305 \pm 5$ and $315 \pm 4$ Ma from Finiels and Bougès facies, respectively (Monié et al., 2000). Furthermore, ${ }^{40} \mathrm{Ar} /{ }^{39} \mathrm{Ar}$ biotite dating indicates cooling ages of $310 \pm 3 \mathrm{Ma}$ for Finiels facies, $311 \pm 3$ Ma for Bougès facies and $309 \pm 3 \mathrm{Ma}$ for the thermal aureole of the Pont-de-Montvert granodiorite (Monié et al., 2000). Consequently, with the available radiometric data, it seems difficult to determine precisely the timing of the emplacement of the different facies. However, according to field structural observations and occurrence of xenolith ( Van Moort, 1966), the Pont-de-Montvert granodiorite intrudes the Signaux pluton.

The structure of the Pont-de-Montvert-Borne granodiorite has already been studied by field and petrofabric structural methods, such as oriented enclaves, aplitic dykes and mineral fabrics (Fernandez, 1977; Mialhe, 1980; Faure et al., 1992 and Faure, 1995). Different hypotheses have been proposed for the 3D shape of the pluton and the tectonic regime of its emplacement. Fernandez, 1977 and Mialhe, 1980 used analyses of K-feldspar megacryst subfabric to argue that the Pont-de-Montvert-Borne granodiorite is a northward dipping granitic sheet that was emplaced during a shortening event. On the contrary, Faure et al. (1992), based on enclaves, cross-joints orientations, biotite and plagioclase subfabrics, considered that this pluton was emplaced during the late-orogenic extension and proposed a laccolith-like shape rooted in its western part and spread toward the east.

\subsection{Country rock structures}

Far away from the borders of the pluton, regional compressional structures (S1 and L1) are well developed. The flat-lying foliation (S1) is axial planar of synmetamorphic isoclinal folds (Faure, 1995 and Charonnat, 2000). The N-S- to NE-SW-trending stretching lineation (L1) is associated with shear criteria indicating a top-to-the-S sense of shear ( Mattauer and Etchecopar, 1977). The S1 foliation is refolded by kilometre-scale E-W- to NW-SE-trending folds overturned to the south. This folding is interpreted as a late increment of the same southward-vergent shearing linked to nappe stacking. These early structures are overprinted by extension-related structures developed both in the pluton thermal aureole and in the host rock micaschists throughout the Cévennes area ( $\underline{\text { Fig. 1b }})$. Stretched biotites along an E-W to NW-SE trend, metre- to millimetre-scale NW-SE upright microfolds, crenulation and penetrative shear bands indicating a top-to-the-SE sense of shear are the best evidence of this extensional event ( Faure et al., 2001).

\subsection{Thermal aureole structures}

Contacts between host rock and granite are generally discordant to the regional foliation of the micaschists. However, another penetrative foliation parallel to the pluton borders develops. This foliation is subvertical along the southern side and dips gently to the north along the northern margin. It is axial planar of E-W- to NW-SE-trending centimetre- to metre-scale folds overturned to the south in the northern flank and upright folds are found along the southern flank (Faure, 1995). Farther from the pluton borders, this foliation and associated folds are rarely observed. Since these structures are not consistent with the regional extensional setting and occur only in the thermal aureole, they were interpreted as due to the pluton growth and not linked to a regional shortening event ( Faure et al., 1992).

In the biotite-, andalusite- and sillimanite-bearing hornfels of the thermal aureole of the granitic massifs, extensional structures are commonly observed. A $\mathrm{N} 80^{\circ} \mathrm{E}-$ to $\mathrm{N} 150^{\circ} \mathrm{E}-$ trending shallowly dipping mineral lineation of biotite and andalusite parallel to a crenulation 
lineation is well developed. Boudinaged andalusite and quartz pressure shadows around biotite porphyroblasts show E-W- to NW-SE-trending stretching. Furthermore, infillings of quartz between andalusite boudins show that stretching is coeval with the crystallization of contact-metamorphic minerals. Along the northern and southern contacts of the pluton, several shear criteria, such as asymmetric pressure shadows, sigmoidal biotite porphyroblasts and shear bands, indicate a top-to-the-E or SE sense of shear (Charonnat, 2000). On the contrary, at the extremities of the pluton, divergent kinematics appear. In the eastern end of the Mont Lozère, the stretching lineation plunges $50-60^{\circ} \mathrm{E}$ and shows normal motion of host rock with respect to the granite. Along the NW boundaries, shear bands and top-to-the-NW shear criteria indicate that the host rock moved downward to the NW. However, in the whole aureole, top-to-the-E sense of shear represents the main kinematics.

\section{Magnetic fabric}

\subsection{Magnetic mineralogy}

An AMS study of the Mont Lozère-Borne complex was carried out since very few mineralpreferred orientations are visible. Details on methodology and magnetic parameters are described in Talbot et al. (2000). The histogram of bulk magnetic susceptibility (BMS) shows weak values for all the granitic facies ( Fig. 2). The BMS values of the Signaux two-mica granite are weaker than Pont-de-Montvert-Borne granodiorite ones (Table 1). They show a monomodal distribution and range from 5 to $120 \times 10^{-6}$ SI with an average of $45 \times 10^{-6}$ SI. For the Pont-de-Monvert-Borne granodiorite, BMS values range from 75 to $255 \times 10^{-6}$ SI with an average of $145 \times 10^{-6}$ SI. These weak values are typical of granites for which main carriers of AMS are paramagnetic phases such as micas, amphiboles or cordierite (Bouchez, 1997). The other magnetic mineralogy analyses (thermomagnetism, isothermal remanence magnetization, microscopic observations) show that micas, mainly biotite, are the main carriers of the susceptibility. Few grains of magnetite and hematite also occur but do not significantly contribute to the AMS. Therefore, the measured AMS fabric pattern corresponds mainly to the mica subfabric. The pole of the magnetic foliation plane $\left(K_{3}\right)$ is orthogonal to the mean orientation of the (001) cleavage of the mica grains. Magnetic lineation $\left(K_{1}\right)$ is parallel to the zone axis of the (001) cleavage of the mica grains.

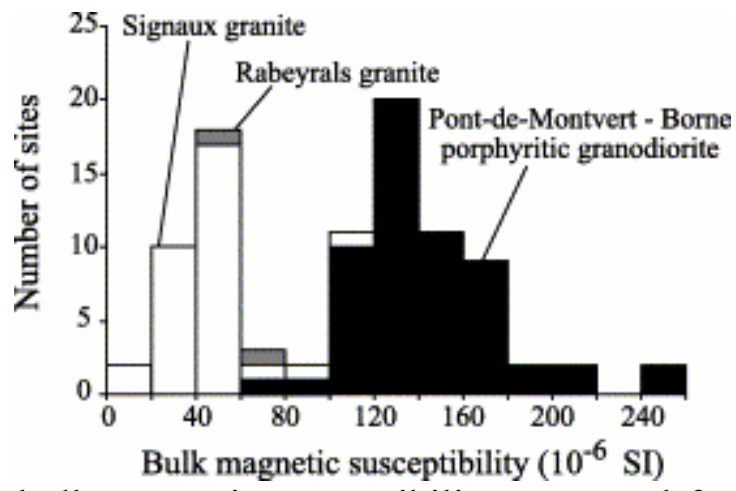

Fig. 2. Histogram of the bulk magnetic susceptibility measured from standard specimens of each sampling site. White, grey and black bars concern Signaux, Rabeyrals and Pont-deMontvert-Borne granites, respectively. 


\begin{tabular}{|c|c|c|c|c|c|c|c|c|c|c|c|c|}
\hline \multirow[t]{2}{*}{ Site } & \multirow[t]{2}{*}{$N$} & \multirow[t]{2}{*}{ BMS } & \multicolumn{4}{|l|}{$\boldsymbol{K}_{1}$} & \multicolumn{4}{|l|}{$K_{3}$} & \multirow[t]{2}{*}{$P^{\prime}(\%)$} & \multirow[t]{2}{*}{$T$} \\
\hline & & & $\mathrm{Dec}$ & Ine & $\alpha_{96 \min }$ & $\alpha_{95 \max }$ & $\overline{D e c}$ & Ine & $\alpha_{96=i n}$ & $\overline{\alpha_{96 m a x}}$ & & \\
\hline $\mathrm{BO} 01$ & 11 & 142.8 & 274.7 & 5.4 & 6.3 & 7.3 & 21.3 & 69.5 & 75 & 19.6 & 45 & -0.434 \\
\hline $\mathrm{BO} 2$ & 9 & 131.6 & 263.5 & 8.1 & 2.7 & 7.5 & 22.4 & 73.3 & 4.1 & 18.2 & 4.1 & -0.379 \\
\hline $\mathrm{BO} 03$ & 11 & 122.9 & 263.9 & 6.3 & 4.3 & 6.4 & 42.0 & 82.0 & 4.8 & 14.6 & 3.8 & -0.445 \\
\hline BOO4 & 13 & 128.1 & 268.7 & 10.0 & 3.9 & 7.7 & 3.8 & 33.1 & 75 & 28.8 & 4.6 & -0.360 \\
\hline BO05 & 19 & 102.3 & 89.0 & 2.8 & 3.0 & 4.9 & 354.6 & 58.8 & 4.4 & 9.9 & 5.3 & -0.315 \\
\hline BO06 & 14 & 134.8 & 267.1 & 11.3 & 5.0 & 8.8 & 358.8 & 33.8 & 8.1 & 25.2 & 3.8 & -0.526 \\
\hline BO07 & 9 & 114.2 & 261.3 & 5.7 & 5.4 & 6.8 & 148.4 & 66.8 & 5.5 & 26.2 & 3.9 & -0.482 \\
\hline BO08 & 8 & 141.7 & 80.9 & 7.5 & 8.3 & 18.0 & 193.6 & 62.9 & 7.2 & 13.4 & 35 & 0.182 \\
\hline BO09 & 4 & 106.3 & 265.3 & 11.0 & 12.8 & 29.5 & 19.6 & 62.7 & 7.0 & 26.9 & 3.2 & -0.474 \\
\hline BO10 & 10 & 135.5 & 87.1 & 3.8 & 3.8 & 10.7 & 292.0 & 83.4 & 5.6 & 20.6 & 4.7 & -0.287 \\
\hline BO11 & 11 & 136.6 & 252.1 & 1.7 & 8.0 & 12.7 & 161.3 & 60.1 & 115 & 14.4 & 3.7 & 0.107 \\
\hline $\mathrm{BO} 12$ & 5 & 132.2 & 255.1 & 2.3 & 4.5 & 9.2 & 350.5 & 58.3 & 7.1 & 41.5 & 2.6 & -0.237 \\
\hline $\mathrm{BO} 13$ & 11 & 123.4 & 273.6 & 23.1 & 7.5 & 16.5 & 119.2 & 67.9 & 9.0 & 17.9 & 3.6 & -0.048 \\
\hline BO14 & 6 & 124.5 & 86.4 & 1.5 & 2.5 & 10.7 & 174.0 & 30.1 & 7.4 & 38.6 & 3.0 & -0.248 \\
\hline BO15 & 10 & 138.9 & 168.7 & 2.0 & 8.1 & 18.8 & 160.6 & 55.5 & 17.8 & 26.7 & 2.6 & -0.153 \\
\hline BO16 & 8 & 126.9 & 257.6 & 51.4 & 10.6 & 15.5 & 126.8 & 31.0 & 10.8 & 21.9 & 7.0 & -0.060 \\
\hline BO18 & 5 & 78.2 & 83.6 & 6.1 & 6.4 & 23.3 & 183.5 & 35.7 & 15.3 & 39.0 & 2.5 & -0.109 \\
\hline BO19 & 6 & 109.3 & 261.8 & 11.3 & 14.9 & 17.0 & 5.0 & 52.3 & 14.8 & 33.3 & 45 & -0.426 \\
\hline BO20 & 8 & 125.5 & 262.5 & 13.8 & 5.4 & 15.4 & 9.1 & 50.9 & 13.1 & 17.2 & 4.6 & -0.129 \\
\hline $\mathrm{BO} 21$ & 5 & 159.3 & 101.2 & 12.1 & 5.9 & 10.6 & 231.1 & 69.7 & 7.8 & 24.4 & 55 & -0.161 \\
\hline $\mathrm{BO} 22$ & 6 & 165.3 & 68.7 & 1.4 & 1.8 & 7.0 & 162.0 & 61.2 & 5.4 & 12.6 & 6.0 & -0.297 \\
\hline $\mathrm{BO} 23$ & 5 & 170.8 & 266.7 & 36.7 & 4.7 & 14.7 & 67.7 & 55.5 & 10.2 & 29.1 & 3.9 & -0.181 \\
\hline BO24 & 6 & 154.5 & 255.5 & 37.2 & 5.9 & 10.6 & 130.0 & 35.2 & 6.4 & 34.4 & 4.2 & -0.387 \\
\hline $\mathrm{BO} 25$ & 4 & 209.0 & 80.8 & 4.5 & 5.3 & 9.8 & 176.4 & 48.0 & 1.1 & 12.0 & 3.2 & -0.265 \\
\hline BO26 & 4 & 157.1 & 267.7 & 1.5 & 2.8 & 16.1 & 33.0 & 73.4 & 4.4 & 48.4 & 3.4 & -0.472 \\
\hline PM27 & 4 & 218.5 & 55.5 & 43.6 & 1.3 & 14.8 & 153.1 & 6.8 & 14.1 & 15.5 & 4.4 & -0.257 \\
\hline PM28 & 5 & 147.7 & 255.6 & 0.9 & 19.7 & 37.6 & 171.5 & 42.8 & 23.8 & 44.6 & 4.7 & 0.110 \\
\hline PM29 & 6 & 167.5 & 256.6 & 13.0 & 2.9 & 8.2 & 358.8 & 42.5 & 8.4 & 27.1 & 4.4 & -0.183 \\
\hline PM 30 & 7 & 127.9 & 245.9 & 10.8 & 10.5 & 16.9 & 354.9 & 63.6 & 7.9 & 28.1 & 7.0 & 0.028 \\
\hline PM31 & 6 & 121.1 & 259.0 & 0.1 & 4.9 & 14.3 & 356.7 & 68.3 & 7.8 & 26.1 & 3.8 & -0.353 \\
\hline PM32 & 4 & 142.3 & 57.7 & 47.1 & 1.5 & 19.6 & 286.2 & 31.3 & 10.4 & 19.5 & 4.2 & -0.417 \\
\hline PM33 & 5 & 120.0 & 75.6 & 19.3 & 4.4 & 15.8 & 168.0 & 19.2 & 15.8 & 43.9 & 5.5 & -0.581 \\
\hline PM34 & 5 & 129.5 & 82.4 & 13.8 & 9.1 & 17.3 & 196.1 & 49.8 & 9.6 & 40.1 & 6.5 & 0.022 \\
\hline PM35 & 5 & 173.7 & 251.8 & 6.7 & 7.8 & 8.0 & 347.3 & 42.4 & 10.1 & 32.0 & 3.8 & -0.334 \\
\hline PM36 & 5 & 256.6 & 234.7 & 28.5 & 6.2 & 16.5 & 44.3 & 99.2 & 4.4 & 40.9 & 1.9 & -0.239 \\
\hline PM37 & 6 & 172.9 & 258.0 & 8.3 & 3.3 & 9.2 & 354.1 & 12.2 & 7.0 & 39.8 & 3.0 & -0.157 \\
\hline PM38 & 7 & 140.3 & 249.6 & 23.9 & 4.8 & 12.0 & 355.3 & 29.3 & 7.0 & 21.9 & 2.3 & 0.005 \\
\hline PM 39 & 4 & 140.1 & 245.0 & 14.6 & 5.6 & 13.2 & 1.4 & 45.9 & 2.7 & 44.9 & 2.4 & -0.167 \\
\hline PM40 & 4 & 81.8 & 105.7 & 10.8 & 19.0 & 35.4 & 336.5 & 42.9 & 1.0 & 49.7 & 2.2 & -0.196 \\
\hline PM41 & 4 & 248.7 & 247.8 & 25.0 & 7.2 & 14.8 & 3.8 & 43.1 & 1.4 & 9.9 & 3.1 & 0.484 \\
\hline PM42 & 5 & 107.7 & 251.3 & 20.0 & 5.1 & 14.0 & 25.5 & 61.6 & 5.9 & 27.9 & 2.9 & -0.194 \\
\hline PM43 & 6 & 153.4 & 269.1 & 41.6 & 11.5 & 21.8 & 44.5 & 41.9 & 9.1 & 24.4 & 2.1 & 0.357 \\
\hline PM44 & 4 & 162.9 & 254.4 & 18.0 & 9.0 & 17.4 & 351.3 & 31.5 & 13.7 & 33.1 & 1.9 & -0.027 \\
\hline PM45 & 4 & 117.0 & 237.4 & 48.8 & 14.5 & 43.9 & 5.0 & 40.5 & 8.1 & 42.7 & 15 & -0.097 \\
\hline PM46 & 6 & 154.4 & 271.2 & 15.8 & 8.5 & 25.6 & 138.9 & 53.8 & 15.2 & 22.7 & 4.7 & 0.226 \\
\hline PM47 & 7 & 166.7 & 263.5 & 2.9 & 6.0 & 8.5 & 158.3 & 74.6 & 6.9 & 16.3 & 2.8 & -0.065 \\
\hline PM48 & 4 & 183.1 & 281.3 & 26.0 & 8.0 & 15.9 & 19.1 & 27.7 & 11.7 & 41.1 & 1.8 & 0.109 \\
\hline PM49 & 7 & 172.3 & 258.3 & 26.5 & 8.4 & 25.4 & 110.2 & 61.6 & 23.6 & 33.9 & 3.8 & 0.056 \\
\hline PM50 & 6 & 138.7 & 272.6 & 3.7 & 4.7 & 29.4 & 169.6 & 68.1 & 6.9 & 21.6 & 2.0 & 0.122 \\
\hline PM51 & 6 & 131.6 & 105.4 & 4.5 & 10.1 & 30.7 & 7.0 & 34.3 & 16.5 & 34.0 & 3.6 & 0.405 \\
\hline PM52 & 6 & 127.7 & 261.7 & 63.5 & 17.7 & 23.1 & 70.0 & 21.5 & 16.0 & 27.9 & 55 & 0.064 \\
\hline PM53 & 7 & 160.7 & 292.5 & 43.3 & 19.5 & 30.8 & 68.6 & 48.1 & 135 & 22.6 & 2.1 & 0.296 \\
\hline PM54 & 6 & 185.1 & 318.3 & 14.9 & 22.6 & 42.2 & 69.0 & 75.3 & 26.8 & 32.7 & 1.8 & 0.003 \\
\hline PM55 & 6 & 133.4 & 263.5 & 7.7 & 22.9 & 33.4 & 176.5 & 16.9 & 20.4 & 28.5 & 1.7 & -0.053 \\
\hline PM56 & 5 & 104.8 & 206.9 & 3.0 & 12.2 & 40.4 & 93.5 & 52.1 & 135 & 25.6 & 3.6 & 0.335 \\
\hline PM57 & 5 & 106.9 & 280.9 & 39.9 & 8.8 & 33.7 & 89.4 & 55.2 & 30.9 & 35.4 & 4.6 & 0.179 \\
\hline L01 & 5 & 31.7 & 296.5 & 3.2 & 9.3 & 38.3 & 178.8 & 56.1 & 11.4 & 19.8 & 5.0 & 0.500 \\
\hline $\mathrm{L} 02$ & 5 & 41.7 & 115.7 & 11.6 & 9.2 & 13.4 & 18.5 & 27.1 & 8.0 & 11.6 & 15.1 & 0.414 \\
\hline
\end{tabular}




\begin{tabular}{|c|c|c|c|c|c|c|c|c|c|c|c|c|}
\hline \multirow[t]{2}{*}{ Site } & \multirow[t]{2}{*}{$N$} & \multirow[t]{2}{*}{ BMS } & \multicolumn{4}{|l|}{$K_{1}$} & \multicolumn{4}{|l|}{$K_{3}$} & \multirow[t]{2}{*}{$P^{x}(\%)$} & \multirow[t]{2}{*}{$T$} \\
\hline & & & Dec & Ine & $\alpha_{96 \min }$ & $\alpha_{96 \max }$ & Dec & Ine & $\alpha_{9 \text { min }}$ & $\alpha_{9 \text { max }}$ & & \\
\hline L03 & 7 & 1159 & 265.2 & 1.2 & 9.9 & 13.2 & 352.0 & 36.9 & 7.2 & 23.2 & 3.8 & 0.320 \\
\hline LO4 & 5 & 58.7 & 260.6 & 7.7 & 11.6 & 34.8 & 3.2 & 105 & 13.5 & 36.5 & 3.0 & 0.122 \\
\hline L05 & 7 & 88.0 & 97.3 & 23.6 & 215 & 28.7 & 188.0 & 11.0 & 23.8 & 38.1 & 2.7 & 0.116 \\
\hline L06 & 6 & 50.5 & 236.4 & 38.4 & 7.9 & 14.7 & 346.2 & 26.1 & 12.2 & 39.5 & 3.2 & 0.151 \\
\hline L07 & 4 & 50.7 & 222.7 & 27.2 & 10.9 & 14.9 & 321.7 & 3.6 & 9.8 & 33.6 & 3.0 & -0.225 \\
\hline L08 & 5 & 54.3 & 2215 & 13.9 & 14.2 & 24.2 & 42.2 & 70.2 & 7.6 & 46.5 & 5.3 & -0.035 \\
\hline LO9 & 7 & 46.3 & 155.2 & 70.8 & 22.7 & 29.8 & 269.8 & 12.3 & 21.7 & 35.1 & 5.0 & 0.032 \\
\hline L10 & 6 & 50.8 & 259.7 & 53.1 & 15.6 & 32.5 & 42.9 & 42.8 & 20.9 & 38.9 & 43 & -0.048 \\
\hline L11 & 6 & 24.9 & 673 & 15.0 & 26.4 & 34.0 & 327.0 & 28.7 & 13.7 & 38.3 & 4.1 & 0.266 \\
\hline L12 & 8 & 223 & 298.1 & 12.4 & 5.0 & 18.6 & 50.7 & 57.7 & 4.0 & 12.3 & 12.0 & 0.502 \\
\hline L13 & 6 & 56.6 & 127.4 & 13 & 7.0 & 8.9 & 217.8 & 23.2 & 6.6 & 12.6 & 3.0 & -0.342 \\
\hline L14 & 4 & 44.5 & 336.0 & 27.7 & 5.3 & 29.6 & 215.6 & 49.9 & 10.8 & 16.0 & 3.8 & 0.410 \\
\hline L15 & 5 & 36.4 & 338.0 & 75.3 & 4.0 & 6.7 & 221.9 & 6.8 & 35 & 8.8 & 6.2 & -0.011 \\
\hline L16 & 4 & 47.5 & 225.2 & 20.1 & 7.1 & 23.5 & 334.4 & 39.9 & 12.4 & 29.9 & 35 & 0.099 \\
\hline L17 & 5 & 53.2 & 124.8 & 1.2 & 63 & 20.3 & 34.9 & 22.7 & 10.5 & 193 & 46 & -0.062 \\
\hline L18 & 6 & 101.8 & 292.2 & 21.2 & 6.7 & 15.5 & 455 & 49.0 & 7.1 & 19.0 & 3.1 & 0.204 \\
\hline L19 & 7 & 102.1 & 103.0 & 1.6 & 7.0 & 20.4 & 15.1 & 56.8 & 6.9 & 18.8 & 3.9 & 0.206 \\
\hline L20 & 6 & 43.6 & 330.0 & 12.0 & 19.6 & 41.8 & 65.5 & 25.0 & 23.6 & 31.2 & 5.1 & 0.218 \\
\hline L21 & 7 & 6.6 & 293.1 & 34.8 & 25.4 & 30.1 & 47.8 & 41.7 & 24.7 & 31.1 & 144.8 & 0.198 \\
\hline L22 & 4 & 54.5 & 254.8 & 17.7 & 14.6 & 22.3 & 349.6 & 13.1 & 6.8 & 16.1 & 65 & 0.240 \\
\hline L23 & 6 & 16.2 & 334.8 & 41.4 & 25.9 & 39.7 & 76.6 & 53.9 & 25.9 & 31.8 & 9.2 & 0.206 \\
\hline L24 & 6 & 37.3 & 104.2 & 14.4 & 22.2 & 32.7 & 9.5 & 27.1 & 20.3 & 28.1 & 43 & 0.384 \\
\hline L25 & 5 & 53.1 & 3235 & 67.8 & 13.1 & 47.4 & 29.7 & 10.2 & 11.0 & 315 & 8.1 & 0.517 \\
\hline L26 & 4 & 74.6 & 222.7 & 43.0 & 9.1 & 22.2 & 3349 & 21.3 & 5.8 & 22.7 & 6.7 & 0.082 \\
\hline L27 & 6 & 57.5 & 175.6 & 45.8 & 14.8 & 30.0 & 49.1 & 47.3 & 113 & 34.4 & 4.4 & 0.193 \\
\hline L28 & 5 & 54.4 & 249.6 & 18.6 & 7.3 & 21.5 & 3373 & 245 & 3.4 & 39.1 & 55 & -0.021 \\
\hline L29 & 7 & 43.2 & 2473 & 26.8 & 9.2 & 22.8 & 128.3 & 45.1 & 11.8 & 315 & 3.4 & -0.031 \\
\hline L30 & 5 & 30.9 & 145.3 & 39.3 & 8.2 & 22.8 & 38.7 & 20.0 & 3.2 & 9.2 & 12.5 & 0.567 \\
\hline L31 & 6 & 26.5 & 275.4 & 245 & 16.8 & 36.6 & 45.9 & 44.3 & 23.4 & 34.9 & 113 & -0.189 \\
\hline L.32 & 5 & 228 & 105.6 & 6.2 & 13.0 & 47.6 & 8.5 & 53.9 & 10.6 & 33.1 & 12.2 & 0.716 \\
\hline L33 & 5 & 31.1 & 271.9 & 21.0 & 22.0 & 39.2 & 350.7 & 0.2 & 19.7 & 29.4 & 6.1 & 0.003 \\
\hline L.34 & 5 & 25.1 & 80.8 & 7.9 & 7.6 & 19.7 & 340.5 & 45.8 & 16.2 & 31.5 & 7.2 & -0.165 \\
\hline L35 & 7 & 57.7 & 52.5 & 67.1 & 22.9 & 35.0 & 334.8 & 21.9 & 265 & 32.1 & 2.0 & 0.107 \\
\hline L36 & 5 & 63.1 & 302.8 & 4.3 & 4.0 & 45.8 & 44.1 & 35.9 & 21.2 & 27.8 & 2.2 & -0.027 \\
\hline
\end{tabular}

Table 1. Anisotropy of magnetic susceptibility data. $N$ : number of specimens; BMS: Bulk magnetic susceptibility in $10^{-6} \mathrm{SI}$; Dec, Inc, $\alpha_{95 \min }, \alpha_{95 \max }$ : declination, inclination, Bingham (1964) bimodal statistics data, respectively, in degrees; $P^{\prime}$ : anisotropy degree; $T$ : shape parameter (Jelinek, 1981 and $\underline{\text { Hrouda, 1982) }}$

\subsection{Fabric pattern}

The AMS was measured for 92 sites, 25 in the Borne massif and 67 in the Mont Lozère massif, and in this latter, mainly in the Signaux pluton and in the Pont-de-Montvert porphyritic granodiorite with 32 and 33 sites, respectively, and 2 sites in the Rabeyrals granite. At a given site, the number of sampled specimens varies between 4 and 19. For each site, the site-average orientation and confidence intervals at the $95 \%$ level, which correspond to the $\alpha_{95 \min }$ and $\alpha_{95 \max }\left(\right.$ Bingham, 1964) was computed for $\mathrm{K}_{1}$ and $\mathrm{K}_{3}$ axes (Table 1). If confidence level of a magnetic axis, $\mathrm{K}_{1}$ and/or $\mathrm{K}_{3}$, is smaller than $20^{\circ}$ within a site, this magnetic axis is considered as well-defined, otherwise it is poorly-defined, that is the siteaverage orientation is not reliable. Fig. 3 shows AMS stereonets for each site in the Mont Lozère complex. Specimen results, average orientations and confidence ellipses are plotted. For the Signaux granite, the site-average orientation is often poorly-defined. Magnetic lineation and foliation are well-defined only within 16 and 11 sites out of 32 , respectively. In the NW part where AMS fabrics are the most well-defined, the lineation trends NW-SE with variable plunge and the foliation strikes NW-SE with moderate or strong dip toward NE or SW. In other parts of the Signaux pluton, the magnetic fabric is poorly-defined (with high $\alpha_{95}$ values for AMS principal axes) and its pattern is more complex. On the contrary, the AMS results are generally less scattered in the Pont-de-Montvert granodiorite (Fig. 3). For a given site, fabrics of all the specimens are better grouped. This is confirmed by the results in the Borne massif where magnetic lineations and foliations are, respectively, well-grouped in 24 
and 18 sites out of 25 ( Fig. 4). As AMS results are generally well-defined in the Pont-deMontvert-Borne porphyritic granodiorite, a more detailed study of this pluton was carried out.

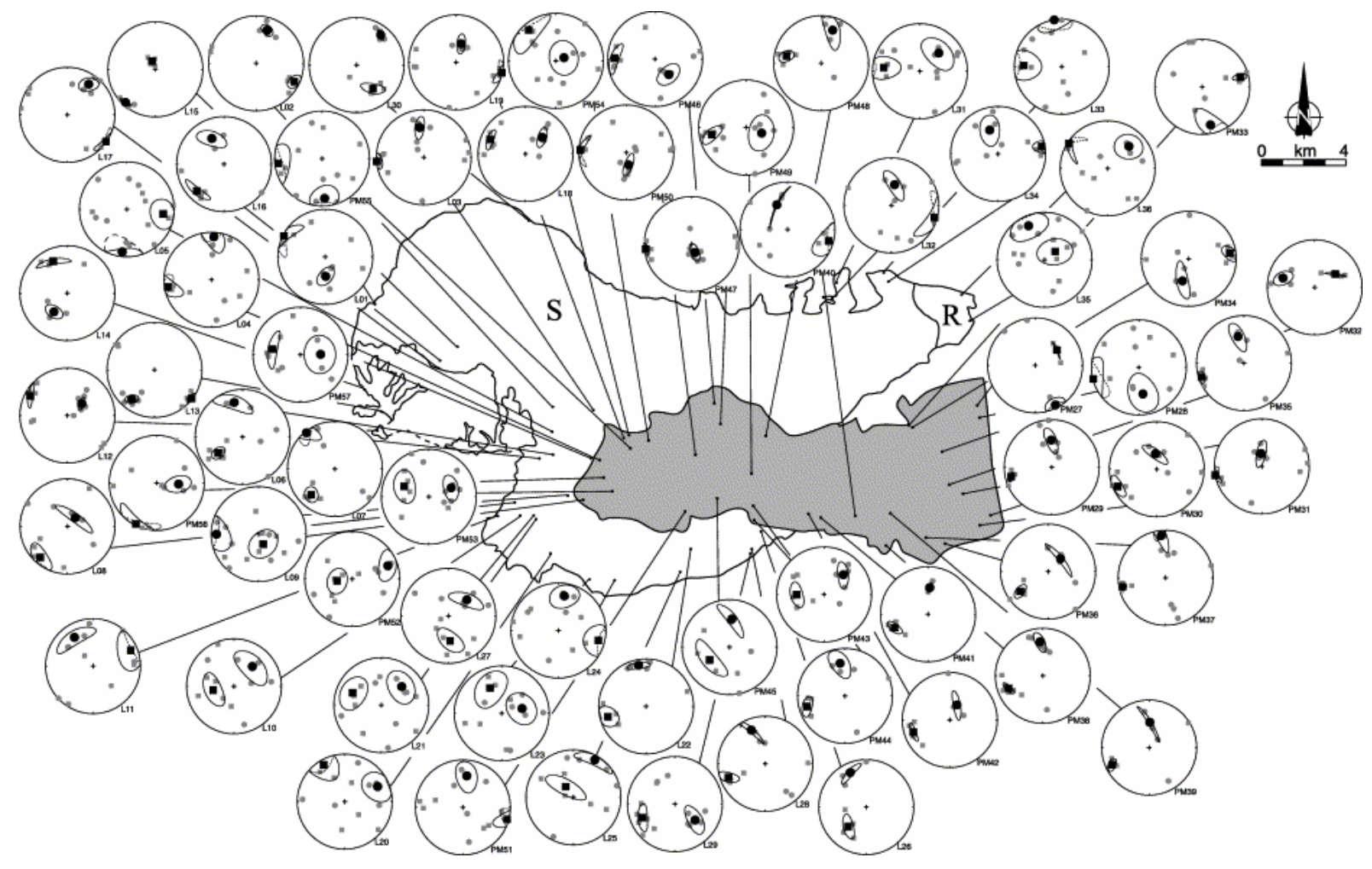

Fig. 3. Equal-area projection of AMS results for each sampling site of the Mont Lozère massif (Grey: Pont-de-Montvert porphyritic granodiorite, S: Signaux two-mica granite, R: Rabeyrals granite). Squares and circles are $K_{1}$ (magnetic lineation) and $K_{3}$ (pole of magnetic foliation), respectively. Small grey dots and larger black ones represent individual specimen and average orientation directions, respectively. Confidence ellipses are drawn around average orientation direction. 


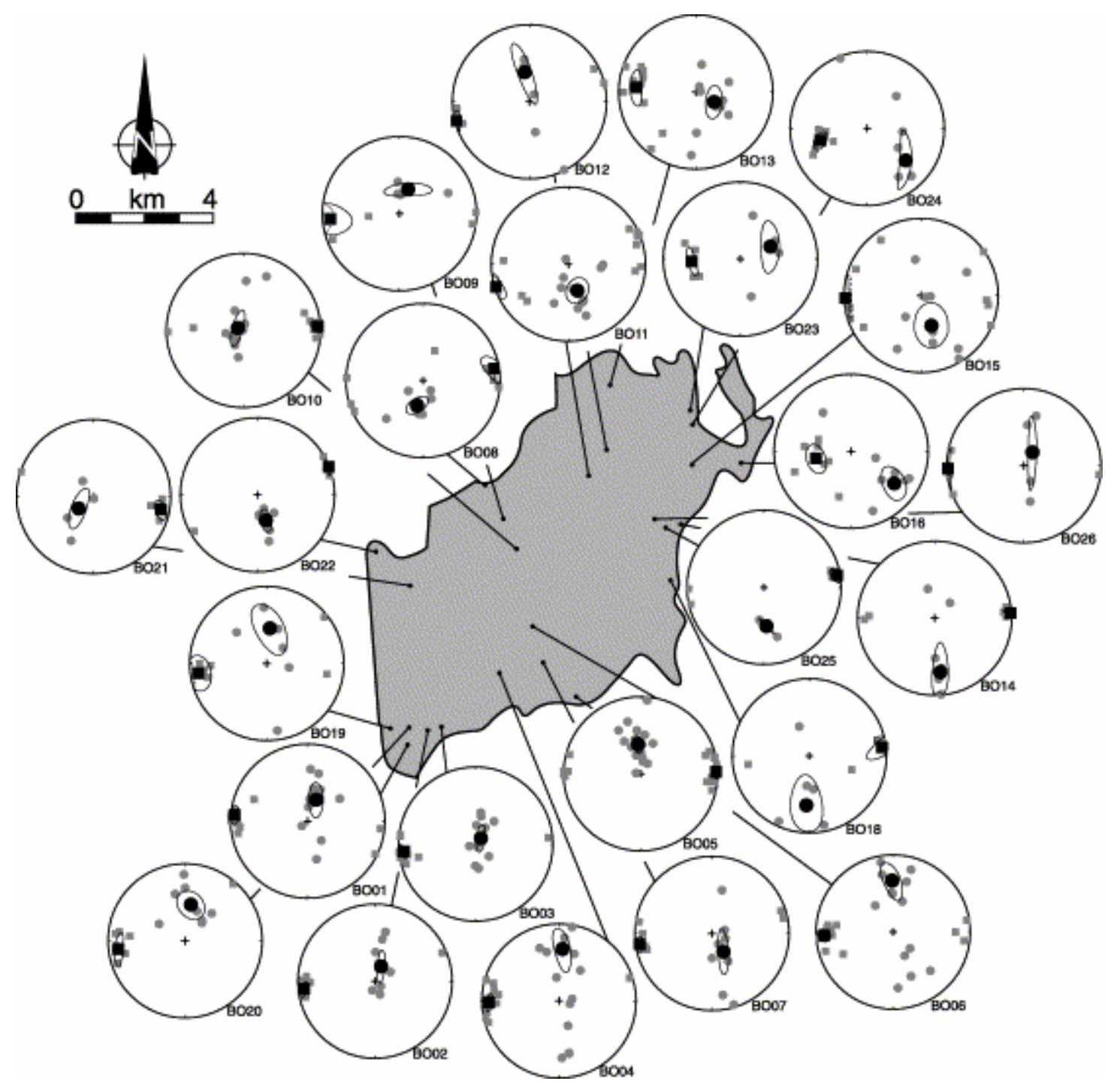

Fig. 4. Equal-area projection of AMS results for each sampling site of the Borne massif. Same captions as Fig. 3.

In this pluton, the main paramagnetic phase is biotite. Like in the Signaux granite, the traces of ferromagnetic phases do not significantly alter the magnetic susceptibility signal given by micas (Talbot et al., 2000). The fabric pattern of this granite shows a well-developed subhorizontal plunging E-W lineation throughout the pluton, particularly in the Borne and the eastern part of the Pont-de-Montvert ( Fig. 5a). However, in the westernmost part of the Pontde-Montvert, some sites do not show this linear preferred orientation. The sites where the lineation is poorly-defined, show either a horizontal or a moderately plunging lineation. The foliation pattern is more complex (Fig. 5b). Generally, the foliation planes dip away from the pluton centre, except in the eastern part of the Borne massif where the trend of the foliation crosscuts the margins. However, the magnetic foliations are often parallel to the borders with steeper dips along the southern border than along the northern one. In the westernmost part of the Pont-de-Montvert massif, foliation planes follow also the margin of the pluton and foliation trends form a curve parallel to the border. Conversely to this well-defined pattern, in the inner part of the pluton, the foliation trends are more scattered with variable dips. 
a Magnetic lineations
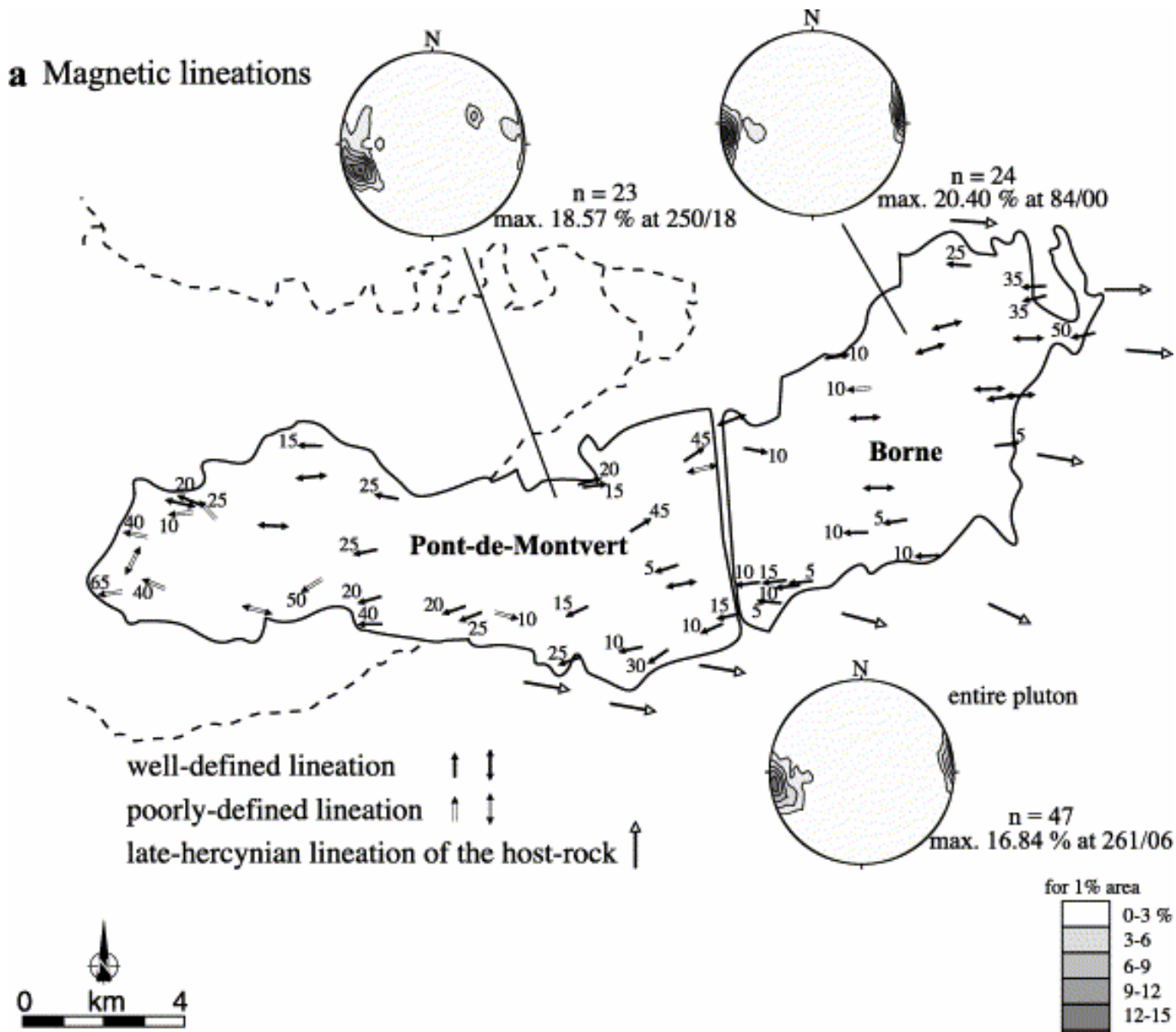

b Magnetic foliations
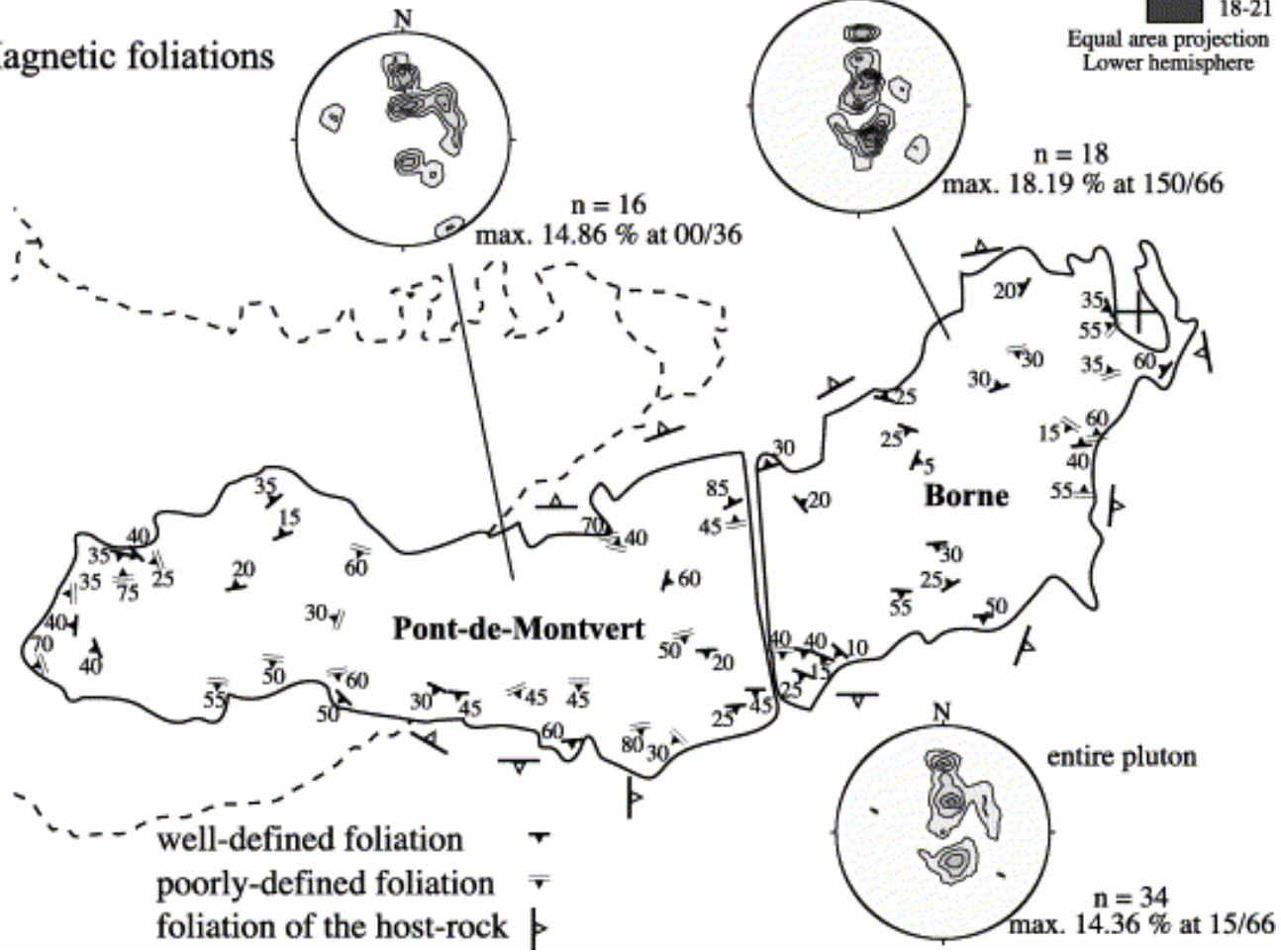

Fig. 5. Magnetic fabric of the Pont-de-Montvert-Borne porphyritic granodiorite. (a) Magnetic lineations. (b) Magnetic foliations. The Borne massif is restored in its initial position before left-lateral displacement along the Villefort fault. On the stereonets, only the data from welldefined sites are plotted. 


\subsection{Scalar magnetic data}

To describe the shape of the AMS ellipsoid, two parameters, $T$ and $P^{\prime}$ (Jelinek, 1978; Jelinek, 1981 and Hrouda, 1982) are computed. The shape parameter, $T$, given by $T=\left[2 \times \ln \left(K_{2} / K_{3}\right) /\left(\ln \left(K_{1} / K_{2}\right)\right]-1\right.$, where $K_{1}, K_{2}, K_{3}$ are maximum, intermediate and minimum axes of the AMS ellipsoid, respectively, indicates the shape of ellipsoid (i.e. prolate or oblate ellipsoid). It allows us to know if the magnetic fabric is rather linear or planar. In addition, the anisotropy degree, $P^{\prime}(\%)=\left\{\exp \sqrt{ }\left[2 \times \Sigma\left(\ln K_{i}-\ln K_{\text {mean }}\right)^{2}\right]-1\right\} \times 100$, where $i=1,2, \quad 3$ and $K_{\text {mean }}=\left(K_{1}+K_{2}+K_{3}\right) / 3$ is an indicator of the intensity of the AMS ellipsoid (Table 1). Prolate type ellipsoids characterize the eastern part of the pluton, i.e. the Borne massif and the eastern part of the Pont-de-Montvert granodiorite ( Fig. 6a), whereas oblate type ellipsoids are predominant in the western part. The $P^{\prime}$ parameter displays low values between 1.7 and $7 \%$ typical of granites where the biotite carries the magnetic signal (Bouchez, 1997). The map distribution of the anisotropy degree shows also a difference between the eastern and western parts of the pluton ( Fig. 6b). Higher values are found in the eastern part, where $P^{\prime}$ ranges from 2.5 to $7 \%$. In the western part, where $P^{\prime}$ is generally weak (lower than $3 \%$ ), few sites located near the pluton borders show stronger values around 3 to $5.5 \%$. Consequently, eastern and western parts of the pluton are characterized by different AMS features. A well-defined horizontal E-W-trending lineation, intense and prolate fabrics are found in the eastern part of the pluton whereas the western part is characterized by more scattered lineations, weaker and oblate fabrics. 


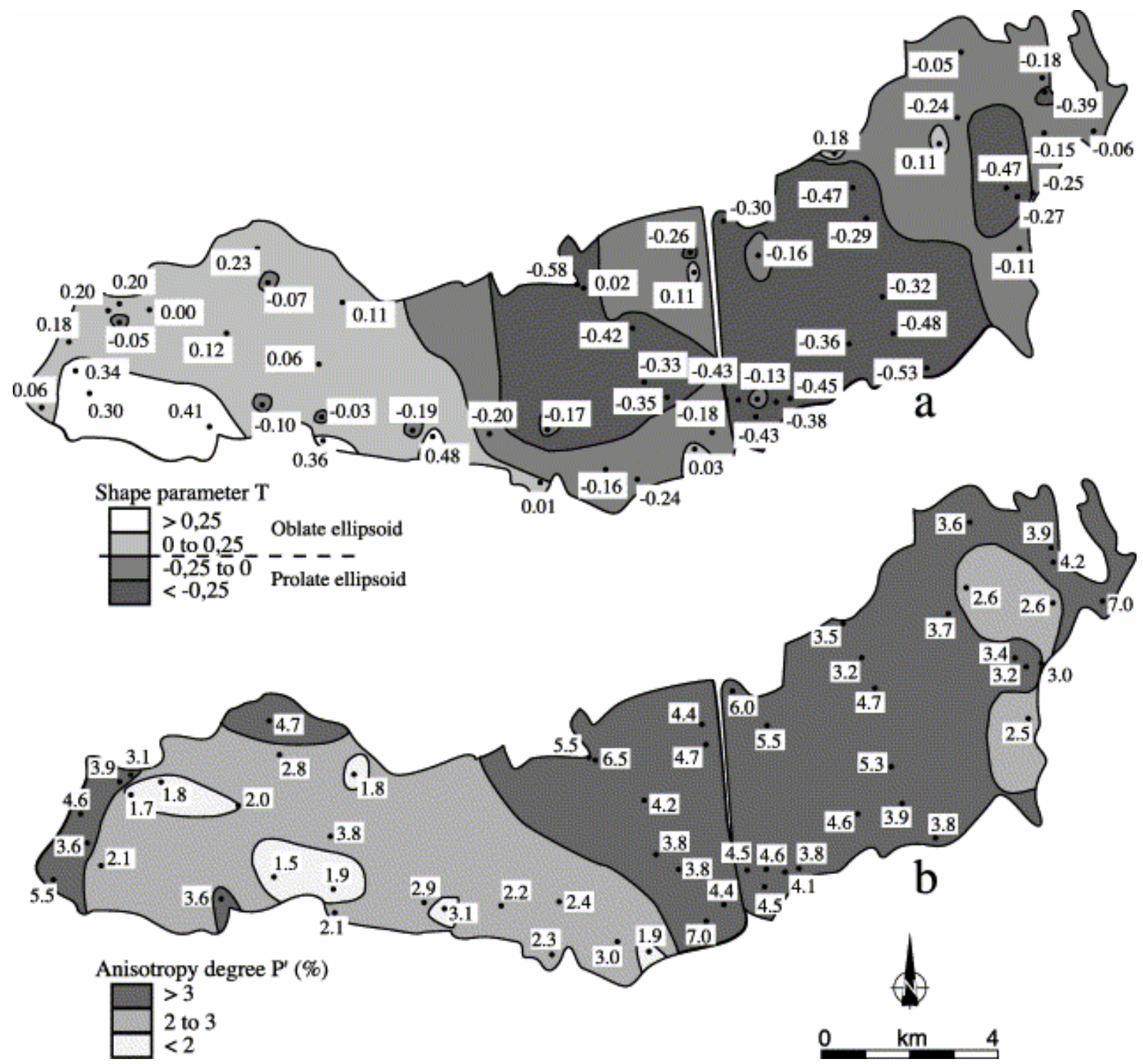

Fig. 6. Map of the scalar parameters. (a) Shape parameter, T. (b) Anisotropy degree, $P^{\prime}(\%)$.

\section{Microstructural observations}

It is important to determine which stage of the crystallization and cooling history the fabrics recorded. A magmatic state fabric is acquired when the granite is still above the solidus, that is during crystallization, whereas a solid-state fabric characterizes subsolidus conditions. Previously, several studies dealing with microstructural criteria to distinguish magmatic or solid-state structures have been presented (e.g. Paterson et al., 1989; Paterson et al., 1998 and Bouchez et al., 1992). In the Pont-de-Montvert-Borne pluton, microstructures are analysed in 29 sampling sites and three main microstructural types are recognized ( Fig. 7). 


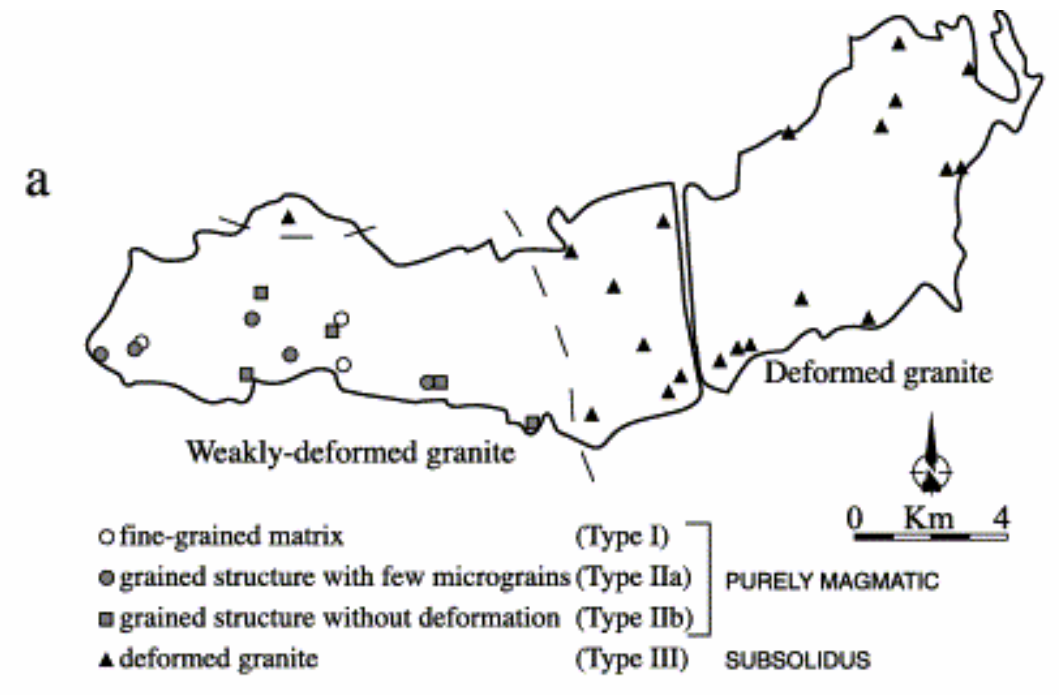

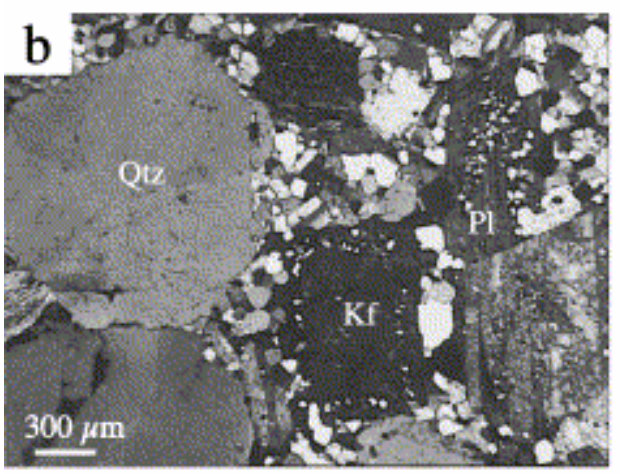

Type I

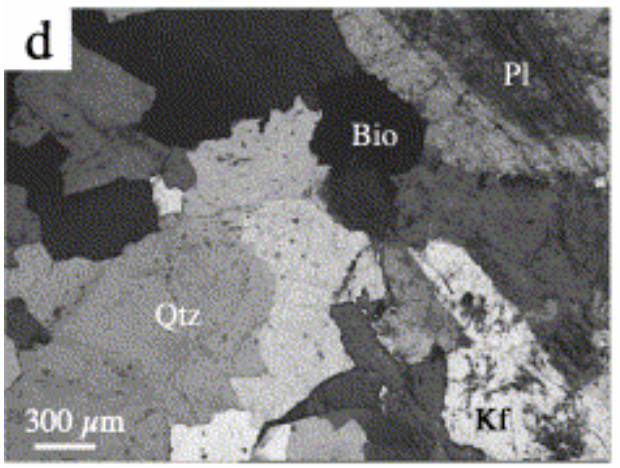

Type IIb

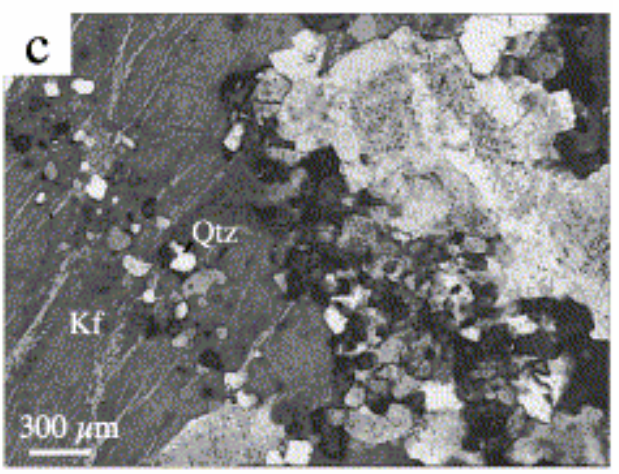

Type IIa

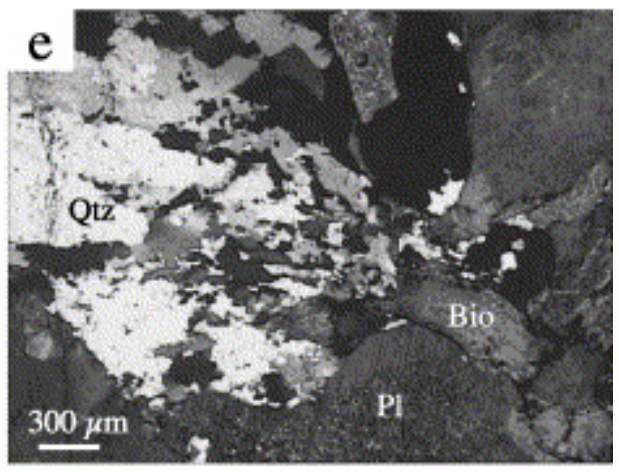

Type III

Fig. 7. (a) Map distribution of the different types of microstructures defined in the Pont-deMontvert-Borne porphyritic granodiorite. (b)-(d) Purely magmatic microstructures which differ from each other by occurrence and amount of micrograins. (e) Subsolidus microstructure showing evidence of high-temperature recrystallization. Qtz: quartz, Kf: Kfeldspar, Pl: plagioclase, Bio: biotite

Type I microstructure: At three sites, located only in the western part of the pluton (Fig. 7a), the granite presents a peculiar facies characterized by rare biotite grains without any evidence of deformation, such as lack of undulose extinction and kinking or bending of (001) cleavage planes ( $\underline{\text { Fig. } 7 \mathrm{~b}}$ ). Millimetre-sized grains of quartz and feldspar are surrounded by a finegrained $(10-100 \mu \mathrm{m})$ quartz-feldspar matrix. The large quartz grains show no sign of undulose extinction or recrystallization. Sometimes, small grains are included into larger grains and can form an inner corona near grain boundaries. In some specimens, myrmekites 
also occur and can be abundant. This microstructure looks like 'melt relocation' texture in which the fined-grained fraction is a result of late-magmatic melt crystallization ( Hibbard, 1987). The absence of deformation criteria shows that type I microstructure formed during the magmatic state.

Type II microstructure: This is the most common type in the western part of the pluton (Fig. 7a). This type is characterized by millimetre-sized rounded quartz grains with slight undulose extinction and very little evidence of recrystallization. Biotite and feldspar do not show any deformation. This microstructural type is subdivided into two subtypes, IIa and IIb ( Fig. 7c and d). The only difference between subtypes IIa and IIb is that the former contains small grains of quartz and feldspar and some myrmekites ( Fig. 7c) indicating slight melt relocation as in the type I microstructure. In the subtype IIa, some K-feldspar grains are fractured with infillings of small grains of quartz, which grew from a quartz crystal outside of the fracture. This latter one corresponds to the submagmatic fractures described by Bouchez et al. (1992). But generally, in type II microstructures ( Fig. 7c and d), significant solid-state deformation has not been observed. Hence, the fabric is probably acquired in the magmatic state but can also record some submagmatic deformation.

Type III microstructure: In the eastern part of the pluton and in one site in the northwestern margin (Fig. 7a), the microstructures differ from that of types I and II. Quartz shows an intensive dynamic recrystallization with numerous subgrains with serrated boundaries. A conspicuous undulose extinction of clasts is developed ( Fig. 7e). Biotites are kinked and bent. However, feldspars do not show any signs of recrystallization or deformation. Furthermore, gneissic structures are absent. Hence, type III microstructure was developed in the solid state, soon after the magma had completely crystallized. Since there is no trace of a later postsolidus deformation (i.e. gneissification) the corresponding fabric was probably acquired in a subsolidus state when the pluton was already crystallized.

The geographic distribution of those three types of microstructures shows an obvious difference between the eastern and western parts of the pluton (Fig. 7a). This map distribution is similar to that of parameter $P^{\prime}$ (Fig. 6b). So, a good correlation between the type of microstructures and $P^{\prime}$ values can be established (Fig. 8). For the sites with magmatic microstructures, $P^{\prime}$ ranges from 1.9 to $3.8 \%$ (Type I) and from 1.5 to $3.6 \%$ (Type II) except for one site with a $P^{\prime}$ value of $5.5 \%$. The sites with subsolidus structures generally have higher $P^{\prime}$ values, from 2.6 to $7.0 \%$. Therefore, samples that experienced a solid-state deformation have a stronger anisotropy degree than those where magmatic structures are preserved. Since no correlation between $P^{\prime}$ and BMS can be established (Table 1), and microscopic observations do not show petrographic differences, such as alteration, between the eastern and western parts of the pluton, the geographic variations of $P^{\prime}$ are not likely due to variations of magnetic properties of our specimens. On the contrary, the higher $P^{\prime}$ values may reflect stronger preferred orientations of the AMS carrier minerals. 


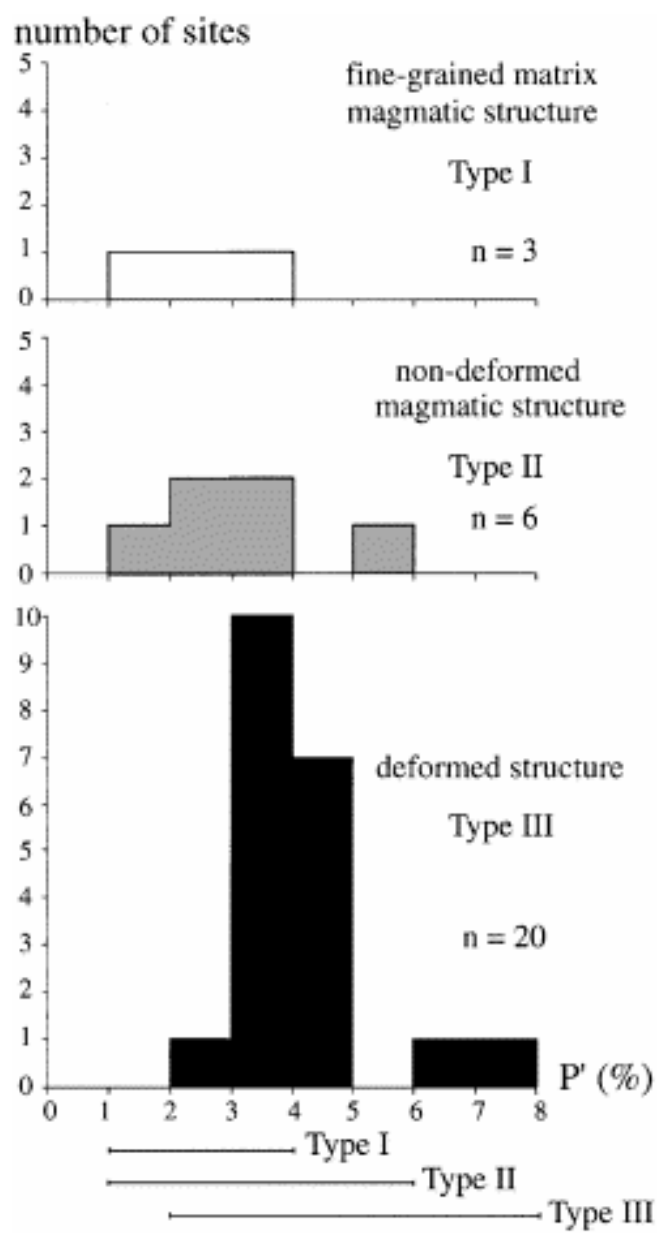

Fig. 8. Histograms showing the relationship between types of microstructure and anisotropy degree, $P^{\prime}(\%)$.

The above-described microstructures are either purely magmatic or formed just after the complete crystallization of the magma (in the subsolidus stage), with no sign of deformation well after complete crystallization. Therefore, the magnetic fabric was acquired during and just after the magma crystallization and was not modified by later events.

\section{Gravity study}

In the Mont Lozère area, since the gravity coverage was not sufficient to perform a detailed gravity modelling, 1200 new gravity stations have been surveyed, as part of GéoFrance 3D program (Martelet et al., 1999). This led to an average coverage of one station per $\mathrm{km}^{2}$, broadly enclosing the outcropping limits of the Mont Lozère and Borne massifs (Fig. 9a). The complete Bouguer anomaly was computed using a reference density of $2.67 \mathrm{~g} / \mathrm{cm}^{3}$ and terrain corrections up to $167 \mathrm{~km}$. Its overall accuracy is better than $1.1 \mathrm{mGal}$ (Martelet et al., 1999). To the first order, long wavelengths of the gravity signal are related to deep sources. As we want to focus on granites that crop out at the surface, the long wavelengths in the Bouguer anomaly have been removed by fitting a polynomial of degree 3 to the gravity anomaly over the entire Massif Central. Fig. 9a shows the resulting residual Bouguer anomaly that represents the effect of density heterogeneities located below the topography, down to a few kilometres. To the first order, the negative anomaly can be correlated to the granite complex, with a clear asymmetry between northern and southern limits of the Mont Lozère-Borne 
complex. To the south, the pluton-host rock boundary is underlined by strong gravity gradients that suggest a steep contact between the two lithologies. To the north, the negative anomaly extends over the metamorphic terrains, suggesting that the pluton gently plunges below the micaschists. Moreover, below the Mont Lozère-Borne complex, a gentle E-Wtrending anomaly suggests that the granite massif becomes thinner eastward.
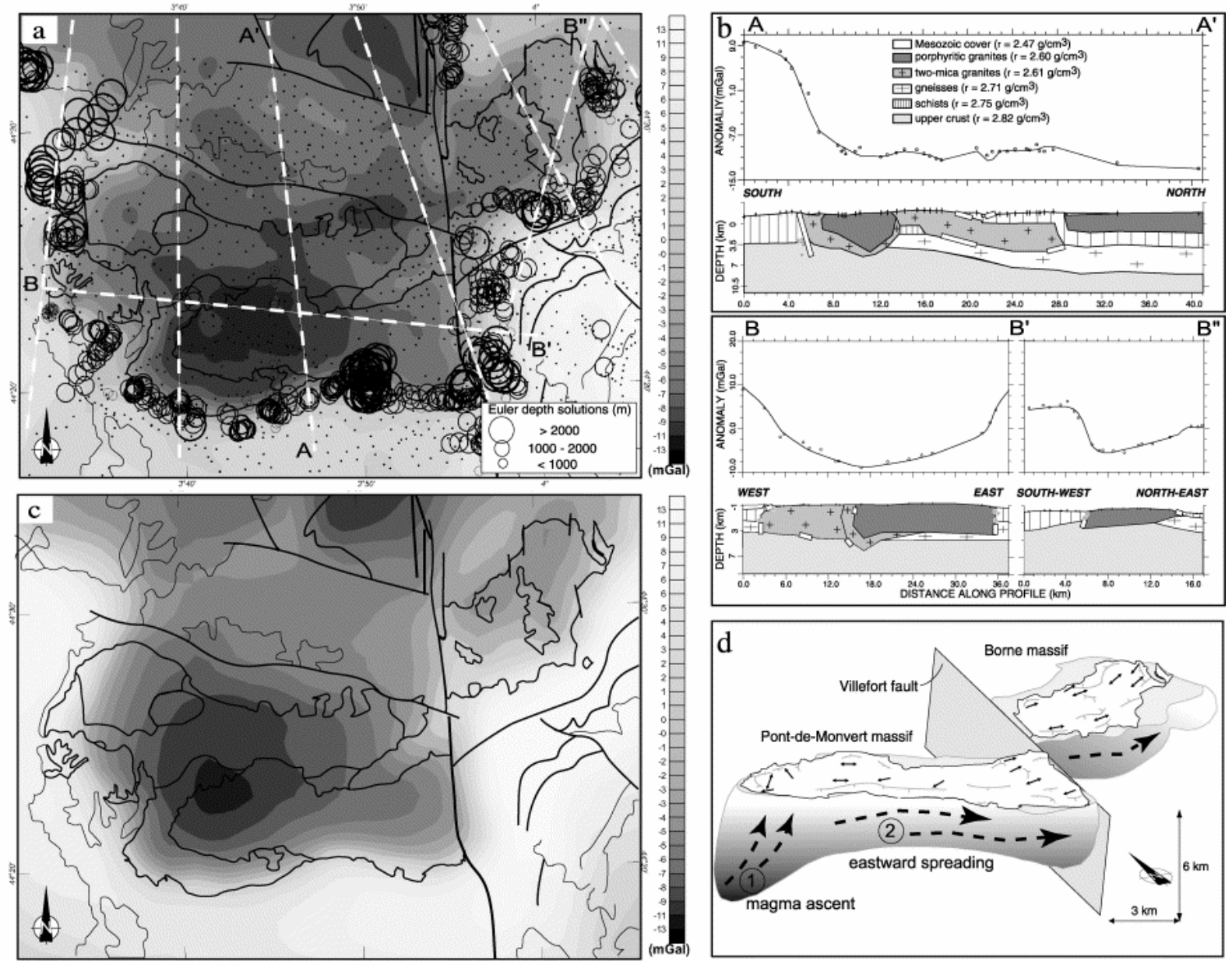

Fig. 9. (a) Map of the residual Bouguer anomaly with location of the gravity stations (black dots). Major geological limits are also drawn (black lines) and location of the gravity profiles used to build the 3D model (white dashed lines). Black circles show the location of Euler sources, with sizes proportional to their depth. They mainly concentrate on the strong gravity gradients of the southern limit of the batholith, which indicates an abrupt contact with the surrounding micaschists. (b) Direct $2 \mathrm{D}$ gravity modelling along $\mathrm{N}-\mathrm{S} \mathrm{AA}^{\prime}$ and $\mathrm{E}-\mathrm{W} \mathrm{BB}^{\prime} \mathrm{B}^{\prime \prime}$ cross-sections. Both models are based on the geology at the surface and the constraints obtained prior to modelling (grey circles show Euler solutions and white bars show sources derived using the wavelet transform analysis). The main particularities on $\mathrm{AA}^{\prime}$ profile are the southern steep limit and northern gentle dip of the granite beneath the micaschists; on $\mathrm{BB}^{\prime} \mathrm{B}^{\prime \prime}$, the $\approx 6-7 \mathrm{~km}$ depth root zone and the progressive thinning of the granite eastward. (c) Gravity effect of the 3D model computed using densities in Table 2. This effect is consistent with the residual Bouguer anomaly in (a). (d) 3D model of the Pont-de-Montvert-Borne granite output from the 'Editeur Géologique' software. The two massifs are presented in their current positions offset by the Villefort fault. Representative AMS foliations (grey) and lineations (black) have been superimposed. 


\subsection{Constraints prior to modelling}

Locating the geological sources responsible for the gravity anomalies is subject to the wellknown non-unicity of causative sources (Roy, 1962). However, in addition to classical direct and inverse modelling approaches, recent advances in potential field analyses (known as 'indirect methods') have greatly improved the accuracy of source characterization (location, depth and shape). In the Mont Lozère area, except the geological map, there is no independent information to precisely constrain the gravity models. Therefore, prior to modelling, indirect analyses applied to the gravity data have been performed, in order to extract quantitative estimates of densities, vertical extents and shapes of the different units involved in the model (Martelet, 1999).

In order to complete the existing density determinations made on several rock samples (Table 2), Nettleton, 1939 and Parasnis, 1952 methods have been applied. Principles of these methods are based on the minimisation of the correlation between the Bouguer anomaly and the topography, depending on the choice of the Bouguer density reduction. These techniques led average densities of $2610 \pm 50 \mathrm{~kg} / \mathrm{m}^{3}$ for the granites and $2750 \pm 50 \mathrm{~kg} / \mathrm{m}^{3}$ for the Cévennes micaschists (ㅁartelet, 1999), in good agreement with rock sample measurements ( $\underline{\text { Table 2)}}$.

\begin{tabular}{|c|c|c|}
\hline Geobged uait & 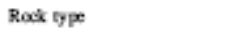 & 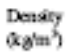 \\
\hline Moumic eaver & Mkinly culcarous solimess & 240 \\
\hline Suphaci a ceal tasia & Sandwer & 250 \\
\hline Micgoille pluosa & Porplynific garaice & 2600 \\
\hline M: Lomte-Hera ganoligrite & Pordyrific garaice & 2509 \\
\hline Mt Loute-Berax lesoograite & leaoograile & 250 \\
\hline Cénarenque unir & Caeiss & 2710 \\
\hline Cerears mesamoplics & Mcanelises & n90 \\
\hline Maracece unit & Geoiss & 200 \\
\hline Buxupper crost & & 280 \\
\hline
\end{tabular}

Table 2. Mean density of lithologic units in the study area. Densities in bold were measured on sampled rocks and/or derived from Nettleton-Parasnis methods and others from the literature

In order to locate the geological structures that are responsible for the measured gravity gradients, Euler deconvolution (e.g. Thompson, 1982) and analytic signal (e.g. Nabighian, 1984) have been used. These methods, based on the combination of derivatives of the field, allow the location of sources of the anomaly, independently from density contrasts. In these methods, geological sources are approximated by simplified bodies (such as punctual, dykelike or step-like sources). The 3D positioning of the sources depends on the appropriate choice of a source type, with an accuracy depending on the noise in the data. Throughout the Mont Lozère massif, when sources are supposed to be step-like (i.e. a contact), both methods provide depth estimates, which represent the half-height of the step-like sources, ranging from 1 to $3 \mathrm{~km}$, mainly delineating the southern limit of the granite massif (black circles in Fig. 9a). Therefore, in its southern part, the step-like sources show that the Mont Lozère massif is about 5-6 km thick (Fig. 9a). This thickness slightly decreases to about 3-4 km on the southern limit of the Borne pluton ( Fig. 9a).

Finally, a 1D wavelet analysis along seven profiles has been performed (see Fig. 9a for their location). This method uses the same simplified description of sources as previous techniques but the wavelet operator allows the simultaneous derivation and upward continuation of the gravity field at several altitudes ( Martelet et al., 2001). Therefore, properties of both operators are combined: accurate location of the sources and analysis of their scaling properties. Independently of the density contrasts, (as in the Euler method), the wavelet-based method is useful for recovering simultaneously the depth, shape factor, approximate dip and 
vertical extent of the sources. Results obtained using this technique are plotted in crosssections (marked by white bars in Fig. 9a) in order to better illustrate their income in terms of geometry of the sources. Globally, location of sources determined by this method fit well with previous estimates (Euler sources), at the southern limit of the massif. In addition, this method allows the retrieval of source-depth information in the northern part of the granite massif, which is crucial to constrain the extension of granite below the micaschists ( Fig. 9b). Wavelet analysis results also provide a more precise description of the sources in terms of their vertical extent, dip and approximate shape. As discussed in the next section, this information is fundamental to constrain the forward gravity modelling, especially to the north of the Mont Lozère massif.

\subsection{D forward gravity modelling}

In order to image the structure of the granitic massif at depth, the residual gravity field has been modelled along seven cross-sections (see Fig. 9a for their location). In this paper, only two of them are presented ( Fig. 9b), one along a N-S-trending profile showing the significant asymmetry between the northern and southern margins of the pluton and the second along an E-W-trending profile showing the eastward thinning of the granite toward the Borne massif. To build these models, the a priori information used, are (1) the geological data such as lithologic distribution, structure..., (2) the geometrical constraints derived by indirect analysis

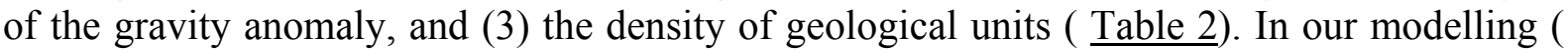
Fig. 9b), the bulk upper crust underlies the migmatitic gneisses and Cévennes micaschists, in which the granites were emplaced. Two types of granites are distinguished: the Pont-deMontvert-Borne porphyritic granodiorite and the Signaux two-mica granite, mainly for a better geological representation, since their densities are too close to each other to produce significant gravity variations. Therefore, the limits between the two plutons have no gravity reliability and only reflect our understanding of the geology. In Fig. 9b, profiles $\mathrm{AA}^{\prime}$ and $\mathrm{BB}^{\prime} \mathrm{B}^{\prime \prime}$ display one possible geometry of the granite complex and its relationships with the host rocks, based on our geological and geophysical knowledge. Vertical extent of the granites derive from our indirect analysis of the gravity field and shapes of the modelled geological units were obtained by fitting the gravity effect of the model ( Fig. 9b, black curve on profile upper window) to the gravity data ( Fig. 9b, dots on profile upper window). Along the N-S AA' profile, when the southern part of the granite is fixed to $5-6 \mathrm{~km}$ (as shown by the indirect analysis), it is not possible to adjust the low anomaly in the northern part of the profile with a single granite/micaschists density contrast: the bottom of the granite under the micaschists would be as deep as $9 \mathrm{~km}$, which is unrealistic compared with granites of the same type studied in this area ( Muon, 1980 and Truffert et al., 1999). Therefore, to be both geologically realistic and consistent with the geophysical constraints, the effect of a deep

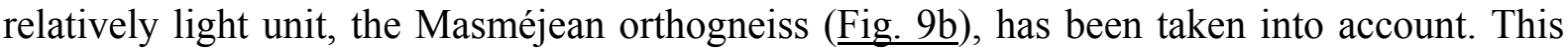
unit crops out in the north of Mont Lozère as a tectonic window, which exposes the deepest part of the para-autochtonous domain of Cévennes (Faure et al., 2001). It is an anticline that plunges to the north below the Velay dome migmatites, to the west below the Margeride pluton, and to the south below the Cévennes micaschists (Fig. 1b). Our modelling further suggests that this unit would possibly extend southward, below the micaschists, and at least below the northern part of the Mont Lozère.

\subsection{Interpretation}

As previously suggested from geological observations (Faure, 1995), the southern limit of the Mont Lozère-Borne complex is steep. Based on geological information and indirect analysis 
prior to direct modelling, the thickness of the pluton varies from 5-6 to 3-4 km from west to east. In the north of the massif, the granite gently dips northward below the Cévennes micaschists. Despite the apparent continuity of the Bouguer anomaly north of the Mont Lozère, Margeride and Mont Lozère plutons are modelled, in agreement with geological constraints, as two distinct bodies separated by the Cévennes micaschists. Furthermore, in the western part of Mont Lozère, the minimum of the Bouguer anomaly is interpreted as the root of the granitic complex. The geometrical characteristics inferred from the gravity study suggest that the porphyritic granodiorite is rooted in its western part and expanded eastward. The Signaux two-mica granite apparently has the same root but is emplaced north- and eastward between the deep Masméjean orthogneiss and the Cévennes micaschists.

\section{3D geometrical modelling}

In order to check the overall 3D consistency of our 2D interpretations, and to highlight the relations between the shape of the Pont-de-Montvert-Borne pluton and the AMS results, a 3D modelling of Mont Lozère-Borne complex has been performed. The 'Editeur Géologique', an original software developed in BRGM (French Geological Survey) is used to model the 3D volumetric bodies (Calcagno et al., 2002). This software allows the integration of various 1D and 2D data such as geological contours, cross-sections, dips, and interpolate them into the whole 3D space. This approach enables us to: (i) validate the $3 \mathrm{D}$ consistency of interpretations coming from separate 2D sources such as map and cross-sections, (ii) construct a 3D model coherent with all available geometric data, including geological contacts and structural dips, and (iii) check and/or refine 3D interpretation by comparing a geophysical measurement, e.g. the Bouguer anomaly, with the gravity effect computed from the model. To build our model in a fully geo-referenced system, we have therefore input (i) a digital topography, (ii) the seven gravity cross-sections and a simplified geological map, and (iii) the dip and strike of foliations and contacts measured in the field. The data were interpolated into 3D using appropriate co-krigging ( Lajaunie et al., 1997). For this step of the model building, a very good consistency of the different sources of data is necessary, otherwise the process will diverge. Some slight adjustments of geometries in our input cross-sections were locally applied, resulting in a 3D topologically coherent model. In order to further insure the 3D consistency of the model with geophysical constraints, the Editeur Géologique allows the computation of the gravity effect of the model. Using the densities given in Table 2, the computation produces a gravity anomaly map ( $\underline{\text { Fig. 9c }}$ ). The comparison of Fig. 9a and c shows that discrepancies between the computed effect and the residual Bouguer anomaly do not exceed a few milligals. Moreover, the main characteristics of the measured gravity anomaly are fairly well reproduced in the model; namely, the higher gravity gradients to the south of the massif, the extension of the negative anomaly to the north of Mont Lozère, and the progressive attenuation of the granite-related negative anomaly from west to east. Compared with 2D modelling, computation of the 3D effect of the model insures (i) that all the complex 3D effects of geological bodies are correctly taken into account, and (ii) that the 3D interpolation in the Editeur Géologique has not induced spurious deformations of the modelled bodies. Although not unique, the model obtained is consistent with the current geological and geophysical knowledge. It displays a coherent 3D vision of the Mont LozèreBorne complex and its relationships with the surrounding terrains. As a part of these results, in Fig. 9d, the 3D model of the Pont-de-Montvert-Borne pluton, on which representative results of the AMS study are reported, is presented (see Section 7 for explanations). 


\section{Discussion}

\subsection{Relationships between magnetic fabric and regional structures}

Microscopic observations show that samples from Pont-de-Montvert-Borne porphyritic granodiorite mainly exhibit two kinds of microstructures. On the one hand, purely magmatic structures are widespread in the western part of the granitic massif. On the other hand, subsolidus structures with minor intracrystalline plastic deformation are found in the eastern part. Although those subsolidus structures record the deformation after the full crystallization of the magma, this deformation is considered as a continuum with respect to the one occurring during the purely magmatic stage, since no later regional deformation occurs. So, the AMS fabric records increments of magmatic deformation during pluton crystallization. However, this fabric may be due either to internal dynamics of the magma body or to a regional strain field. The similarity between regional extensional and thermal aureole structures shows that minerals formed during contact metamorphism (andalusite, biotite), that is during pluton emplacement and crystallization, underwent the regional extensional tectonic event. The corresponding $\mathrm{E}-\mathrm{W}$ - to $\mathrm{NW}-\mathrm{SE}-$ trending lineation is parallel to the magnetic lineation exhibiting a clear E-W trend in the porphyritic facies and NW-SE orientation in the northwestern part of the Signaux granite. Similar structural patterns between the host rock and the pluton are interpreted as evidence that the pluton fabric is induced by the regional deformation (Paterson et al., 1998). Furthermore, stretched minerals, such as boudinaged crystals, have been observed with the $\mathrm{E}-\mathrm{W}$-trending lineation in the host rock. Although microscopic observations do not show a significant amount of stretching in granite samples, the occurrence of $\mathrm{E}-\mathrm{W}$-trending elongated enclaves and $\mathrm{N}-\mathrm{S}$-trending leucogranitic dykes considered as cross-joints, i.e. perpendicular to maximum incremental stretching direction ( Faure et al., 1992), indicates that the E-W-trending elongation is probably also recorded in the granite. Therefore, the AMS fabric pattern shows that the crystallization of Mont LozèreBorne complex is coeval with the E-W to NW-SE extensional event.

\subsection{Emplacement model}

In order to understand emplacement mechanisms of plutons, structural and gravity survey results must be combined. The gravity study allows the inference that the thickest part of the pluton is located in its western part, and that its thickness decreases eastward. Such local thickening part is often interpreted as an indicator of root or feeder zones of plutons (Vigneresse, 1990). This suggests that in the case of the Pont-de-Montvert-Borne pluton, the magma fed the pluton from its current western part and then spread eastward ( Fig. 9d). It is worth noting that the E-W trend of the spreading is parallel to the regional extension direction. Furthermore, the eastward spreading of the magma is in agreement with the general top-to-the-E sense of shear of country rock micaschists. This suggests that the spreading of the pluton has been guided by the regional tectonic regime. The regional extensional tectonics that are characterized by a vertical shortening and a NNE-SSW shortening may have

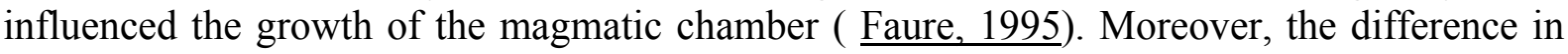
microstructural types between the western and eastern parts of the pluton (purely magmatic vs. slight dynamic recrystallization, respectively) may be explained by the fact that the eastern part of the pluton experienced a regional scale shearing strain at the latest stage of its emplacement during magma spreading or just after the full-crystallization. An alternative explanation of the E-W microstructural evolution is the fact that the eastern part is hosted by micaschists whereas the western part of the pluton is surrounded by the Signaux granite. This latter was probably not entirely crystallized when the porphyritic facies intruded it. Hence, the 
eastern part might record the regional strain more easily than the western part, which was 'protected' by its magmatic host and was less sensitive to the regional tectonics. This last point can also explain the more regular fabric pattern in the eastern area. If the eastward spreading of the Pont-de-Montvert-Borne granite is well constrained by gravity data, the emplacement mode for the Signaux granite is more problematic. As demonstrated by gravity results, the Signaux pluton seems to share the same feeder zone as the Pont-de-MontvertBorne pluton. Gravity also allows the inference that the Signaux granite dips northward below the host micaschists. Except in the northwestern part of the pluton where NW-SE-trending magnetic lineation may indicate that granite expanded northwestward, AMS results do not support a northward dipping of the Signaux pluton. Indeed, the few AMS measurements in the NE part of the granite show more or less an E-W-trending lineation and an E-W-trending foliation with subvertical or southward dips. Very few field observations indicate a northward dip of the Signaux pluton under the host rock micaschists. A more detailed structural study along the northern border of the pluton, where outcropping conditions are generally poor, is necessary to solve this problem. Nevertheless, the fact that the Signaux and Pont-deMontvert-Borne plutons emplaced within a short time span, implies that their emplacement settings are the same. The Mont Lozère-Borne granitic complex was emplaced in a NW-SE to $\mathrm{E}-\mathrm{W}$ extensional regime, though only the Pont-de-Montvert-Borne porphyritic granite preserves well documented constraints on the tectonic setting.

\section{Conclusions}

The Mont Lozère-Borne granitic complex (south French Massif Central), which consists of two plutons, the Signaux two-mica granite and the Pont-de-Montvert-Borne granodiorite, was emplaced at the end of the Hercynian orogeny during the late-orogenic extension. The gravity survey allowed us to determine the 3D shape of the plutons and a structural study, particularly thanks to the AMS investigation of the pluton internal fabrics, showed the relationships between the regional extension and the magmatic fabrics. The most negative gravity anomaly is located in the western part of the granitic complex. This anomaly is interpreted as a feeder

zone. For the Pont-de-Montvert-Borne pluton, we consider that the magma ascended in the western part and then spread eastwardly. The occurrence of magmatic to subsolidus microstructures shows that the internal plutonic fabrics were acquired during or shortly after the crystallization of the magma. The agreement between NW-SE- to E-W-trending regional extensional structures with the directions of AMS lineations of the pluton demonstrates that the pluton internal fabrics recorded some increments of the late-orogenic extension event. Therefore, the emplacement of the Mont Lozère-Borne complex occurred during the general collapse of the Hercynian belt, and apparently, its emplacement mode was influenced by the regional tectonics. These results allow the inference that the Cévennes area was already in extension around $315 \mathrm{Ma}$.

\section{Acknowledgements}

This paper is a contribution to GéoFrance 3D. 2D gravity modelling was performed using GM-SYS Geosoft package. S. Paterson and K. Benn are thanked for their constructive remarks to improve a first draft of the manuscript. 


\section{References}

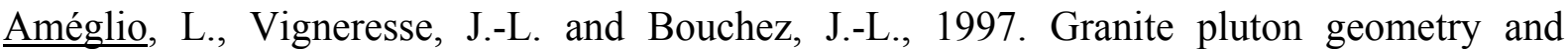
emplacement mode inferred from combined fabric and gravity data. In: Bouchez, J.-L., Hutton, D.H.W. and Stephens, W.E., Editors, 1997. Granite: From Segregation of Melt to Emplacement Fabrics, Kluwer Academic Publishers, Dordrecht, pp. 199-214.

Benn, K., Horne, R.J., Kontak, D.J., Pignotta, G. and Evans, N.G., 1997. Syn-Acadian emplacement model for the South Mountain Batholith, Meguma Terrane, Novia Scotia: magnetic fabric and structural analyses. Geological Society of America Bulletin 109, pp. 1279-1293.

Benn, K., Paterson, S.R., Lund, S.P., Pignotta, G.S. and Kruse, S., 2001. Magmatic fabrics in batholiths as markers of regional strains and plate kinematics: example of the Cretaceous Mt. Stuart batholith. Physics and Chemistry of the Earth 26, pp. 343-354.

Bingham, C., 1964. Distribution on a sphere and on the projective plane. Ph.D. thesis, Yale University.

Borradaile, G.J. and Kehlenbeck, M.M., 1996. Possible cryptic tectono-magnetic fabrics in 'post-tectonic' granitoid plutons of the Canadian Shield. Earth and Planetary Science Letters 137, pp. 119-127.

Bouchez, J.-L., 1997. Granite is never isotropic: an introduction to AMS studies of granitic rocks. In: Bouchez, J.-L., Hutton, D.H.W. and Stephens, W.E., Editors, 1997. Granite: From Segregation of Melt to Emplacement Fabrics, Kluwer Academic Publishers, Dordrecht, pp. 95-112.

Bouchez, J.-L., Delas, C., Gleizes, G., Nédélec, A. and Cuney, M., 1992. Submagmatic microfractures in granites. Geology 20, pp. 35-38.

Brown, E.H. and Talbot, J.L., 1989. Orogen-parallel extension in the North Cascades Crystalline Core, Washington. Tectonics 8, pp. 1105-1114.

Brown, M. and Solar, G.S., 1998. Granite ascent and emplacement during contractional deformation in convergent orogens. Journal of Structural Geology 20, pp. 1365-1393.

Calcagno, P., Martelet, G., Gumiaux, C., 2002. Apport de la modélisation géométrique 3D à l'interprétation géologique du complexe de Champtoceaux (Massif Armoricain). Proceedings of the 19th Réunion des Sciences de la Terre.

Caron, C., 1994. Les minéralisations $\mathrm{Pb}-\mathrm{Zn}$ associées au Paléozoïque inférieur d'Europe méridionale. Traçage isotopique $\mathrm{Pb}-\mathrm{Pb}$ des gîtes de l'Iglesiente ( $\mathrm{SW}$ Sardaigne) et des Cévennes et évolution de socle encaissant par la géochronologie $\mathrm{U}-\mathrm{Pb},{ }^{40} \mathrm{Ar}-{ }^{39} \mathrm{Ar}$ et $\mathrm{K}-\mathrm{Ar}$. $\mathrm{Ph} . \mathrm{D}$. thesis, Université de Montpellier II, 288pp.

Charonnat, X., 2000. Les minéralisations aurifères tardi-hercyniennes des Cévennes (Massif central français). Cadre structural, gîtologie et modélisation 3D. Ph.D. thesis, Université d'Orléans, 260pp. 
D'Lemos, R.S., Brown, M. and Strachan, R.A., 1992. Granite magma generation, ascent and emplacement within a transpressional orogen. Journal of the Geological Society, London 149, pp. 487-490.

Faure, M., 1995. Late orogenic carboniferous extensions in the Variscan French Massif Central. Tectonics 14, pp. 132-153.

Faure, M., Pons, J. and Babinault, J.-F., 1992. Le pluton du Pont-de-Montvert: un granite syntectonique extravasé vers l'Est pendant le désépaississement crustal varisque du Massif Central français. Comptes Rendus de l'Académie des Sciences de Paris 315, pp. 201-208.

Faure, M., Leloix, C. and Roig, J.-Y., 1997. L'évolution polycyclique de la chaîne hercynienne. Bulletin de la Société géologique de France 168, pp. 695-705.

Faure, M., Charonnat, X., Chauvet, A., Chen, Y., Talbot, J.-Y., Martelet, G., Courrioux, G., Monié, P. and Milési, J.-P., 2001. Tectonic evolution of the Cévennes para-autochthonous domain of the Hercynian French Massif Central and its bearing on ore deposits formation. Bulletin de la Société géologique de France 172, pp. 687-696.

Fernandez, A., 1977. Sur la structure et mise en place du granite porphyroïde du Pont-deMontvert (Mont Lozère, Massif central français). Comptes Rendus Sommaire de la Société géologique de France 3, pp. 137-140.

Gleizes, G., Leblanc, D. and Bouchez, J.-L., 1997. Variscan granites of the Pyrenees revisited: their role as syntectonic markers of the orogen. Terra Nova 9, pp. 38-41.

Hibbard, M.J., 1987. Deformation of incompletely crystallized magma systems: granitic gneisses and their tectonic implications. Journal of Geology 95, pp. 543-561.

Hrouda, F., 1982. Magnetic anisotropy of rocks and its application in geology and geophysics. Geophysical Surveys 5, pp. 37-82.

Jelinek, V., 1978. Statistical processing of anisotropy of magnetic susceptibility measured on groups of specimens. Studia Geophyzika et Geodetika 22, pp. 50-62.

Jelinek, V., 1981. Characterization of the magnetic fabric of rocks. Tectonophysics 79, pp. $563-567$.

Lajaunie, C., Courrioux, G. and Manuel, L., 1997. Foliations fields and 3D cartography in geology: principles of a method based on potential interpolation. Mathematical Geology 29, pp. 571-584.

Ledru, P., Lardeaux, J.-M., Santallier, D., Autran, A., Quenardel, J.-M., Floc'h, J.-P., Lerouge, G., Maillet, N., Marchand, J. and Ploquin, A., 1989. Où sont les nappes dans le Massif central français?. Bulletin de la Société géologique de France 5, pp. 605-618.

Lyons, J.B., Campbell, J.G. and Erikson, J.P., 1996. Gravity signatures and geometric configurations of some Oliveran plutons: their relation to Acadian structures. Geological Society of America Bulletin 108, pp. 872-882. 
Malavieille, J., 1993. Late orogenic extension in mountain belts: insight from the Basin and Range and the late Paleozoic Variscan Belt. Tectonics 12, pp. 1115-1130.

Martelet, G., 1999. Modélisation de la structure crustale et du comportement mécanique de la lithosphère à partir des anomalies gravimétriques. Applications à l'Himalaya et au massif granitique du Mont Lozère, Cévennes. Ph.D. thesis, Institut de Physique du Globe de Paris, $324 \mathrm{pp}$.

Martelet, G., Diament, M. and Truffert, C., 1999. Un lever gravimétrique détaillé dans les Cévennes: apport à l'imagerie crustale (programme GéoFrance 3D-Massif central). Comptes Rendus de l'Académie des Sciences de Paris 328, pp. 727-732.

Martelet, G., Sailhac, P., Moreau, F. and Diament, M., 2001. Characterization of geological boundaries using 1-D wavelet transform on gravity data: theory and application to the Himalayas. Geophysics 66, pp. 1116-1129.

Mattauer, M. and Etchecopar, A., 1977. Argumentation en faveur de chevauchements de type himalayen dans la chaîne hercynienne du Massif Central français. Colloque International CNRS 268, pp. 261-267.

Matte, P., 1986. La chaîne varisque parmi les chaînes paléozoïques péri atlantiques, modèle d'évolution et position des grands blocs continentaux au Permo-Carbonifère. Bulletin de la Société géologique de France 8 1, pp. 9-24.

Mialhe, J., 1980. Le massif granitique de la Borne (Cévennes). Etude pétrographique, géochimique, géochronologique et structurale. Ph.D. thesis, Université de Clermont-Ferrand, $171 \mathrm{pp}$.

Monié, P., Respaut, J.-P., Brichaud, S., Bouchot, V., Faure, M., Roig, J.-Y., 2000. ${ }^{40} \mathrm{Ar} /{ }^{39} \mathrm{Ar}$ and $\mathrm{U}-\mathrm{Pb}$ geochronology applied to $\mathrm{Au}-\mathrm{W}-\mathrm{Sb}$ metallogenesis in the Cévennes and Châtaigneraie districts (Southern Massif Central, France). In: Orogenic Gold Deposits in Europe, Document BRGM 297, Bureau de Recherches Géologiques et Minières, Orléans, pp. $77-79$.

Muon, P., 1980. Etude gravimétrique du massif du Mont Lozère et du Rouergue occidental. DEA (Master Thesis), Université de Montpellier II.

Nabighian, M.N., 1984. Toward a three-dimensional automatic interpretation of potential field data via generalized Hilbert transform. Geophysics 49, pp. 957-966.

Nettleton, L.L., 1939. Determination of density for the reduction of gravimeter observations. Geophysics 4, pp. 176-183.

Parasnis, D.S., 1952. A study of rock densities in the English Midlands. Monthly Note Royal Astronomical Society, Geophysics Supplement 6, pp. 252-271.

Paterson, S.R., Vernon, R.H. and Tobisch, O.T., 1989. A review of criteria for the identification of magmatic and tectonic foliations in granitoids. Journal of Structural Geology 11, pp. 349-363. 
Paterson, S.R., Fowler Jr., T.K., Schmidt, K.L., Yoshinobu, A.S., Yuan, E.S. and Miller, R.B., 1998. Interpreting magmatic fabric patterns in plutons. Lithos 44, pp. 53-82.

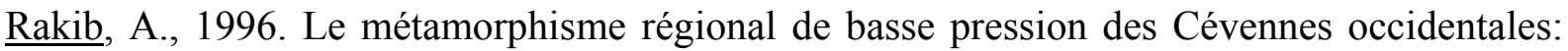
une conséquence directe de la mise en place du dôme thermique vellave (Massif Central français). Ph.D. thesis, Université de Montpellier II, 207pp.

Roy, A., 1962. Ambiguity in geophysical interpretation. Geophysics 27, pp. 90-99.

Scaillet, B., Pêcher, A., Rochette, P. and Champenois, M., 1995. The Gangotri granite (Garhwal Himalaya): Laccolithic emplacement in an extending collisional belt. Journal of Geophysical Research 100 B1, pp. 585-607.

Talbot, J.-Y., Chen, Y., Faure, M. and Lin, W., 2000. AMS study of the Pont-de-MontvertBorne porphyritic granite pluton (French Massif Central) and its tectonic implications. Geophysical Journal International 140, pp. 677-686.

Thompson, D.T., 1982. EULDPH: a new technique for making computer-assisted depth estimates from magnetic data. Geophysics 47, pp. 31-37.

Truffert, C., MCF3D team, 1999. 3D crustal scale modelling in the Massif Central. In: Colloque GéoFrance3D-Résultats et perspectives, Document BRGM 293, Bureau de Recherches Géologiques et Minières, Orléans, pp. 37-45.

Van Moort, J.-C., 1966. Les roches cristallophyliennes des Cévennes et les roches plutoniques du Mont Lozère. Ph.D. thesis, Université de Clermont-Ferrand, 272pp.

Vigneresse, J.-L., 1990. Use and misuse of geophysical data to determine the shape at depth of granitic intrusions. Geological Journal 25, pp. 249-260.

Vigneresse, J.-L. and Bouchez, J.-L., 1997. Successive granitic magma batches during pluton emplacement: the case of Cabeza de Araya (Spain). Journal of Petrology 38, pp. 1767-1776. 